Portland State University

PDXScholar

Summer 1-1-2012

\title{
Euthanasia, the Ethics of Patient Care and the Language of Propaganda
}

\author{
Elizabeth Maria Krapf \\ Portland State University
}

Follow this and additional works at: https://pdxscholar.library.pdx.edu/open_access_etds

Part of the Ethics and Political Philosophy Commons, German Language and Literature Commons, Military and Veterans Studies Commons, and the Other Psychiatry and Psychology Commons Let us know how access to this document benefits you.

\section{Recommended Citation}

Krapf, Elizabeth Maria, "Euthanasia, the Ethics of Patient Care and the Language of Propaganda" (2012). Dissertations and Theses. Paper 606.

https://doi.org/10.15760/etd.606

This Thesis is brought to you for free and open access. It has been accepted for inclusion in Dissertations and Theses by an authorized administrator of PDXScholar. Please contact us if we can make this document more accessible: pdxscholar@pdx.edu. 
Euthanasia, the Ethics of Patient Care and the Language of Propaganda

by

Elizabeth Maria Krapf

A thesis submitted in partial fulfillment of the requirements for the degree of

Master of Arts

in

German

Thesis Committee:

Steven N. Fuller, Chair

Natan Meir

William Fischer

Portland State University

(C)2012 


\begin{abstract}
This thesis is an examination of euthanasia, eugenics, the ethic of patient care, and linguistic propaganda in the Second World War. The examination of euthanasia discusses not only the history and involvement of the facility at Hadamar in Germany, but also discuss the current euthanasia debate. Euthanasia in World War II arose out of the Nazi desire to cleanse the Reich and was greatly influenced by the American eugenics movement of the early $20^{\text {th }}$ century. Eugenics was built up to include anyone considered undesirable and unworthy of life and killed many thousands of people before the invasion of allied troops in 1944. Paramount to euthanasia is forced sterilization, the ethic of patient care, and how the results of the research conducted on euthanasia victims before their deaths should be used. The Nazis were able to change the generally accepted terms that researchers use to describe their experiments and this change affected how modern doctors and researchers use the terms in current research. This thesis includes research conducted in Germany and the United States from varied resources.
\end{abstract}




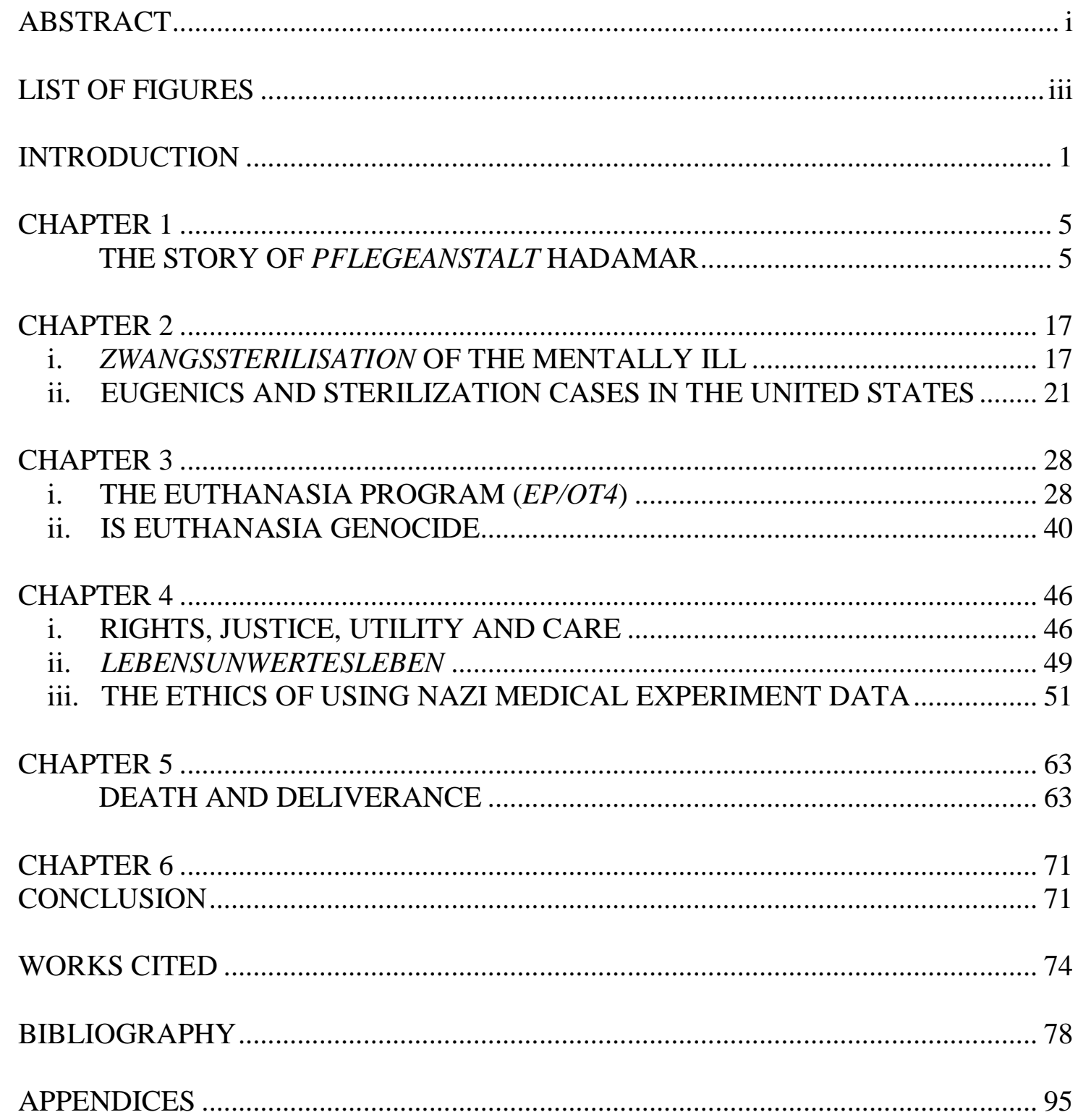


List of Figures

Figure 1: Map of Euthanasia Program in Germany 1940-1945, p. 27 


\section{INTRODUCTION}

The Second World War left a clear imprint on the minds of historians, writers and ethicists owing to the atrocities that occurred at the hands of the Nazis. While the Holocaust was terrible, some of the programs leading to the Final Solution had an original basis in utility and a desire to help a broken country to return to its former greatness. After World War I, Germany was a broken country, financially strapped, without food, without a strong leader, and angry - angry because of the humiliation of military defeat and because of reparations required of them by the Allied victors. All these disappointments led to the rise of Adolf Hitler and his fervent desire to return Germany to the status of world power with an indestructible race of Aryans who would repopulate the world.

Adolf Hitler's original idea of restoring Germany's power and awe had specific material causes, but the implementation of his idea became the most discussed war of all time. The laws and programs designed by his National Socialist colleagues led to the death of six million Jews, Gypsies, and homosexuals. It also to a change in language that continues to affect how physicians and scientists write research articles and even how they conduct their research. The brilliant propaganda machine designed by National Socialism made the mandatory sterilization of those deemed inferior an accepted action and additionally helped justify what was utilitarian murder, or the EP/OT4. This program, while practical to a Reich at war, violated general ethics, medical ethics and research ethics in its zeal to rid the Reich of Erbkrankheiten and strengthen the human race so as to ensure they would always be victorious. But victory at any cost proved to be unrealistic and those involved in the pruning of the human race were eventually caught 
and most brought to justice. The perpetrators of the EP/OT4 and the staff from Pflegeanstalt Hadamar committed murder, made unethical decisions as to the mortality of the Erbkrank, and as a defense claimed they followed orders and had no choice in the matter.

EP/OT4 was a program designed to enhance the German race and to end genetic diseases like alcoholism, promiscuity, and schizophrenia. The initial desire may have been positive, but the end result was mass murder of people who the Nazis deemed unworthy of life. This program was the precursor for the Final Solution. Euthanasia in itself is supposed to be a graceful and painless end to death, but it became so perverted that its' connotation has turned dark. However, euthanasia is not a strong enough word to describe the murders committed and the argument as to whether euthanasia is genocide is integral. While genocide encompasses a vast number of crimes, there is no specific provision for euthanasia itself. Euthanasia in the Second World War was a terrible crime and deserves a term of its own.

Adding euthanasia to The Convention on the Prevention and Punishment of the Crime of Genocide gives the perpetrators a specific crime to be convicted of. Embodied in euthanasia is the precursor to EP/OT4, Zwangssterilisation or forced sterilization. Forced sterilization of the mentally ill started in the late 1930s in Germany as a result of eugenic practices in Germany and influence from the United States. Sterilization was enforced through courts and those who suffered sterilization were eventually interred in places like Hadamar where the EP/OT4 would eventually kill thousands of people.

The death of the mentally ill at Hadamar violated not only basic human morals, but also the ethics of patient care. Doctors and nurses swear an oath not to harm their 
patients and through forcible sterilization and euthanasia, not only did they cause their patients harm, they were responsible for their deaths. This responsibility violates basic ethics and makes EP/OT4 and Zwangssterilisation unethical. The ethics of patient care were altered during World War II and this caused a change in how doctors and nurses treat current patients. Patient care requires a new level of ethics and attention in order to avoid a situation where patients can be harmed.

In addition to changes in patient care, there is also a question of what to do with the research and results from Nazi medical experiments. It is a difficult situation to address as each research professional feels differently based on religion, research area, and educational background. The final decision needs to be made on a case by case basis, depending on the research involved and whether or not it can positively benefit modern medicine. However, some researchers and commentators believe that the research results should not be used under any circumstances as the use insults those who died during the experiments. In the end, the decision to use the results of Nazi research should be clear: use the research if it benefits modern medicine.

Modern medicine, however, has been greatly affected by the Nazi medical experiments. Terms that are generally used in medical and scientific research changed and took on new meanings as a result of the success of Nazi propaganda. Words that all researchers are familiar with took on a meaning that requires modern researchers to use their terms more carefully with credence to the past. Standard language no longer is accepted for what it is and terms must be carefully defined to avoid bringing back their propagandist meaning. 
Michael Burleigh tends to avoid the topic of propaganda in his discussion of EP/OT4. Death and Deliverance gives a vivid picture of the people whose lives ended during EP/OT4 and the origins of the program as well. His gives the reader a more than accurate account of the background leading up to EP/OT4 and the reasons why it was able to continue throughout the war. His discussions and descriptions are mostly fair and while he is indignant, Burleigh recognizes the importance of the horror experienced at places like Hadamar. His book is both terrible in its topic, but brilliant in its detail. His story telling ability leave the reader with a permanent picture of the suffering experienced by those the Nazis deemed unworthy to live.

The EP/OT4 had a variety of outcomes and effects on the world of research, medicine, and history itself. It provided numerous unnecessary medical experiments, benefits to modern day medicine, and a redefinition of common research terms and ideas. EP/OT4 was a negative program that included deaths for sport, survivors who claim their experiences were designed to torture and kill, and modern medicine that is limited in the scope of human experimentation and the possibility to give terminal patients the choice to end their lives. The negatives of EP/OT4 far outweigh the positives, however, the positive aspects including currently used hypothermia treatments and the development of antibiotics, must be recognized. The propaganda machine, the physicians and the leaders of the EP/OT4 managed to change history both for the better and the worse, taking with them six million Jews and hundreds of thousands of mentally and physically handicapped people and leaving behind a legacy of ethically problematic scientific studies. 


\section{CHAPTER 1}

\section{THE STORY OF PFLEGEANSTALT HADAMAR}

Hadamar is a beautiful little town between Cologne and Frankfurt am Main in the German state of Hesse. This town is approximately 500 years old and is charming, straight out of Grimms' Fairytales. While Hadamar is beautiful and charming, its history from the end of the first World War to the end of the second World War also holds horror: murder, the infamy of "life unworthy of life" and a fierce dedication to National Socialism. These afflictions are not Hadamar's only claims to fame: Hadamar is also known for the "Hadamar Baroque" style of building altars that is familiar throughout Germany and the art world. Considering the aforementioned historic era, altars and ovens appear to be very ironic.

In 1883, Eduard Zais built the Corrigendenanstalt, a predecessor to today's Hadamar Centre for Social Psychiatry. In 1906 it was converted into a care facility for the mentally ill of the region. It had previously been a stopover for vagrants and the poor, but was rarely filled to capacity nor was it known to be troublesome. But in the 1930's Hadamar became a frightening place, devoid of caring. Only after the National Socialists came to power in the 1930s did Hadamar become a killing facility (ca. 1941). The killing The American Journal of Psychiatry confirms that the EP/OT4 was the Nazis' first extended campaign of mass murder and it was also the first time in history that medical doctors and psychiatrists participated in the systematic extermination of their patients, whom they felt were "life unworthy of life" and a drain and burden on the Reich's economy. The order was posthaste at the direction of Adolf Hitler's personal physician Karl Brandt and Brandt's cohort, Philip Bouhler. Today, in addition to a 
memorial commemorating the killing of some 15,000 mentally ill, handicapped, Jews, Ostarbeiter and Hälflinge, the buildings of the NS-Totüngsanstalt Hadamar are now the Clinic for Forensic Psychiatry.

The Allies uncovered the atrocities as they captured Hadamar towards the end of World War II (ca. March 1945). In fact, the Hadamar Trial was the first war crimes trial after the end of the war and prosecutors managed to indict several doctors and nurses who had run the facility throughout the war. The historic trial became the impetus for all the medical and physician trials after World War II. From January 1941 until August of 1941, some 10,000 mentally and physically disabled Germans were gassed to death at Hadamar, using carbon monoxide under the ruse of a shower. Although killings were briefly halted in September 1941 on order from the Führer, the killings resumed quickly thereafter and continued until 1945. During this continued period of EP/OT4, another 4400 people were killed at Hadamar. The gassings were officially halted by 1942, but the remaining inmates still housed at Hadamar were either given lethal doses of drugs like morphine, or were simply neglected until they died of malnutrition, etc. Included in the nearly 15,000 murdered at Hadamar were Ostarbeiter, Hälflinge, the mentally ill, and even German soldiers who had either been deemed too ill to recover from their war injuries, or who were too mentally damaged from their war experiences.

\section{Hadamar}

An hour's drive from Frankfurt am Main, you arrive at Hadamar. Today, Hadamar has a population of approximately 10,000 and “...from 1940 to 1945 , the Heilund-Pflegeanstalt was one of the main centers where mentally ill patients were killed by 
the so-called EP/OT4 organization (Meusch, 65). The EP/OT4 was a Nazi operation designed to euthanize as many Erbkrank-those with angeborenem Schwachsinn, Schizophrenie, zirkulärem (manisch-depressivem) Irresein, erblicher Fallsucht, erlichem Beistanz (Huntingtonische Chorea), erblicher Blindheit, erblicher Taubheit, schwerer erblicher Körper Missbildung--and Lebensunwertesleben as possible so as to strengthen the German race. The list of people who were subject to this program eventually expanded to include those who were mentally retarded or suffering from alcoholism, hyper promiscuity, and general insanity. Hadamar gassed and cremated approximately 10,000 mentally ill adults between January and September of 1941. After a brief hiatus, Hadamar resumed killings using lethal doses of medication or starvation diets. The physicians and psychiatrists at Hadamar removed and examined organs of the deceased and then buried the bodies in mass graves at the property. On March 26, 1945 the Allied forces liberated Hadamar and the killing center was closed soon thereafter.

In total, the EP/OT4/Aktion T-4 (hereafter EP/OT4) ended 200,000 lives at places like Hadamar all over Germany. With the passing of the Gesetz zur Verhütung erbkranken Nachwuchses in July of 1933, the Nazis legalized sterilization of Germans suffering from hereditary illnesses, many of these sterilizations taking place at Hadamar. This law was the precursor to the euthanasia they then proceeded to carry out. Hadamar and its staff were complicit in both forced sterilizations and euthanasia. The physicians gave no deference to the kind of ailment each patient was suffering from or whether or not it was really curable and many of these patients' lives ended at the hands of the Hadamar staff. 
The staff of Hadamar argued that the impetus of the euthanasia program was not actually killing at all. It was compulsory sterilization of Germans with the aforementioned diseases and disorders. The Law for the Prevention of Hereditary Diseased Offspring also gave birth to appellate courts established under the law to expedite the sterilizations which had to be carried out no more than two weeks after the verdict came down from the appellate judges. The physicians were not responsible for the sterilizations as they were simply following the law. The judges often sent defendants to Hadamar for the sterilization procedure as the judiciary itself did not have the proper medical facilities. According to Matthias Meusch, between 1934 and 1945, 400,000 men and women were forcibly sterilized, many of them died from complications of the surgery and from depression over losing their ability to have children.

Hadamar's part in the EP/OT4 was as a final destination for the German Erbkrank and Lebensunwertesleben. The mentally ill would be transferred from other asylums within Germany to Hadamar via bus, up to several hundred people a day. This order authorized doctors to kill adults suffering from "incurable" diseases, but "they had to follow, as the order said, the highest standards of scrutiny; the killing itself was supposed to be a mercy death" (Meusch, 65). The Nazi doctors at Hadamar encountered a new level of irresponsibility that was not just about killing, but more about remorseless actions that eventually led the way to industrialized murder in the Nazi concentration camps.

Hadamar was a well-oiled machine, with transports coming in, people being killed, ovens burning their remains and formal letters announcing these deaths to their families, letters that were absolute lies. The families of the victims were at times 
accepting of the letters they received from Hadamar staff, but still others (and many people in and around Hadamar itself) were suspicious of the sudden and seemingly random deaths of their family members and the bizarre diseases that killed them. The oath required them not to cause their patients any undue harm or to provide them with the means to kill themselves, nor to kill their patients themselves. ${ }^{1}$ Every oath they took was broken and abused repeatedly as innocent people, people incapable of defending themselves against the Hadamar staff who carted them to their deaths in buses, stripped them naked, humiliated them and ultimately brutally ended their lives:

“...in Hadamar local 'death buses' collected patients from transfer institutions....At the killing center, the arriving patients were met by the staff and led to the reception room by a male or female nurse, who might have accompanied them on their trip; clerical workers also often performed this function. At the reception area, the patients were told to undress. Usually a transport was composed of either males or females; if it contained both, however, separate facilities for undressing were provided. The patients' clothing and other belongings were sorted, labeled, and given a number; patients believed that this was done so that all items could eventually be returned to the rightful owner, but obviously it served the purpose of efficient disposal after death. Thereafter, the patients were measured and weighed."

The linguistic change to transport in vans from transport in death buses gave the victims a false sense of safety, most thinking that they were just going on a field trip or to a new facility. The Nazis took even more advantage of mentally diminished people by manipulating language and also violated their trust.

\begin{abstract}
"After the reception process, the naked patients were taken one at a time into the examination room, where a physician briefly examined each patient. This was not a regular medical examination, however; the physicians serving in the killing centers did not have the experience, training, or qualifications to make psychiatric evaluations. Together with the office staff present in the examination room, the physician established the identity of the patient on the basis of his or her medical records, and with "relative speed," he "gained a general impression from those people."
\end{abstract}

\footnotetext{
${ }^{1}$ Physicians have been asked to take the Hippocratic Oath since it came into existence in the 5th century BC.
} 
The process of parading the victims through a faux examination and stealing their personal items only added to the humiliation experienced by Hadamar victims before their untimely deaths via gassing. The observation of each victim determined only what the ultimate cause of death would be, whether it was a feasible cause of death or not. The Nazis were looking for a way to make death announcements and justifying the deaths easier.

"....the checking of medical records by a physician in a white coat provided the deceptive appearance of normality. The physician, however, used the period of observation to gain ideas about the fraudulent cause of death he would later have to certify....at this point, another mark was made on the naked bodies of the patients; those possessing gold teeth or gold bridges...This mark later served to identify corpses with valuable dental work.

\begin{abstract}
After all examination and other formalities were completed, the patients, still naked, were assembled so that they could be led into the gas chamber...the gas chambers were located in the basement and patients were led from the photo room back to the examination room and from there through a steel door into the gas chamber..... Once all the patients had entered the gas chamber, the staff closed the steel door and made sure that the door and the ventilation shafts were hermetically sealed. The physician in the adjacent room then opened the valve of the compressed gas canister..." (Friedlander 94-96)
\end{abstract}

At the end of their lives, the people who died at Hadamar were only herded masses who died at the hands of a calculating force of physicians and nurses whose only excuse for continuing the gassings was to rid the Reich of the canker.

In his book The Origins of Nazi Genocide: From Euthanasia to the Final Solution, Henry Friedlander addresses the process through which asylum inmates in places like Hadamar were examined, documented, and eventually euthanized. The process was universal at German asylums. As the war continued and began to turn against the Nazis, the charade became less important. What Friedlander's text indicates is a clear production facility or slaughterhouse treatment of the EP/OT4 victims. Instead of kindness and reassurance of a medical facility, the victims, stripped not only of their 
clothes and belongings, the Hadamar patients lost their humanity and dignity. The Nazi desire to dehumanize and exterminate, along with the need to cleanse the German race was the point of the EP/OT4 at Hadamar and at other such slaughterhouse facilities throughout Germany.

Some of the patients at Hadamar became suspicious during the examination process and upon being led towards the gas chamber, became difficult and attempted escape. These patients were often sedated and sometimes, simply shot to avoid more chaos. Hadamar was able to burn one to two bodies at a time, but as the site killed more and more people, the crematorium became overwhelmed. Smoke billowed from the chimneys at Hadamar and the townspeople began to realize what was going on at the asylum, though they did little to help. It was often joked that one should be careful not to end up in the chimneys at Hadamar. As the "death buses" and trains came in to Hadamar, the farmers were known to remove their hats as the trains and buses drove by to honor those who were inside the vehicles. The people in the town of Hadamar were clearly aware of the murders that were going on. Children often threatened their friends by saying that they had better watch out, or they would end up in the murder buses at Hadamar. The smoke curled up from the chimneys at Hadamar and the foul stench of charred hair and skin permeated the town. Michael Burleigh mentions that workers from Hadamar would often imbibe a bit too much and relate their job responsibilities to the regulars at a local tavern. These blabbermouths often found that they quickly went the same way as their victims once their indiscretions were made known to their superiors (Burleigh). 
In addition to suspicious townspeople, the families of the murdered patients were often confused as to the fate of their loved ones. Hadamar staff had a list of sixty or so different diagnoses that they used as a cause of death. These causes of death were determined during the examination process based on the physical look of each patient and any scars or deformities they might already have. The lack of veracity indicates they were trying to hide something. The letters sent to the victims' family were often abrupt with few details as to a victim's last days. Often, the victim would be transferred from one asylum to Hadamar and die within hours of arrival. The family would only find out of the transfer and subsequent death when they received word that their loved one had died. Meningitis, pneumonia and strokes were popular causes of death. Each letter, though generally vague, would attempt to include some small identifying factor, like the existence of a ring or small possession that the family would recognize (Burleigh, 147-8). Additionally, the letter would request proof of being a legitimate heir and whether or not the family wanted the victim's ashes in an urn. The reason given for cremation was often that the incurably mentally ill carried contagious diseases and their corpses therefore needed to be burned immediately upon death. The letter would also explain that the victim's death must be regarded "as a form of deliverance" (Burleigh 148) and should be met with relief and even thanks. While most families accepted these letters without questions, others became suspicious and wrote letters to the Nazi government (which were ignored) and the asylum director. Their letters were generally ignored. Relatives tried to visit Hadamar to get information about their loved ones and their belongings to 
no avail. The Nazis denied them access to physicians, medical records, belongings, and death certificates. $^{2}$

Lebensunwertesleben was a terrible distinction that the Nazis gave to people who were Erbkrank through no fault of their own. It caused the Erbkrank to be sterilized against their will, it caused them to go before Hereditary Courts who ordered them to be institutionalized until the EP/OT4 became active. This process became the institution of death. The National Socialists set up an institution to convict and process victims.

Perhaps the sterilizations met the ethic of utility at a practical wartime level, but the killings accomplished nothing more than saving the Reich money and depriving happy, productive, and loving people of their right to live.

Hadamar was a miserable place that lost its original purpose through Nazi laws and the desire to improve the strength of the German people. Patients at Hadamar hoped for a safe place to live and to receive care that would make their lives more comfortable. Hadamar the Pflegeanstalt, instead became Hadamar, euthanasia facility and institution of death.

\section{The Hadamar Trial}

The trial of Hadamar physicians and other staff was the first of its kind after the end of World War II. The 1945 Hadamar Trial, the official designation, took place from October 8 to October 15 in the U.S. Zone of post war Germany. This legendary trial would become the basis for all of the mass atrocity/genocide trials that commenced after the Nazi defeat. Allied forces discovered the euthanasia facility at Hadamar in March of

\footnotetext{
${ }^{2}$ Archiv der Gedenkstätte Hadamar-“Christa M.”
} 
1945. The shock and disgust of the Allies pushed the victors to entreat U.S. military authorities to begin legal action against the perpetrators at Hadamar. Though the Americans were unable to prosecute the staff at Hadamar for murdering their own countrymen, Allied lawyers found a loophole in the German law. The loophole allowed Allied prosecutors to file charges of murder and war crimes/crimes against humanity against the Hadamar staff for these crimes committed against Soviet and Polish inmates at their facility. Seven former Hadamar physicians, nurses and staff were brought up on charges of crimes against humanity, which included genocide. ${ }^{3}$ Two physicians were hanged. The other Hadamar staff received jail sentences, including Nurse Irmgard Huber, who received a 25 year sentence. ${ }^{4}$

There were a number of issues that were not legal issues per se, but had a great effect on the Hadamar Trial. After interviewing many of the doctors and nurses who were part of the killing squad at Hadamar, it became clear to prosecutors that the nurses and physicians were under no pressure or coercion to stay at Hadamar, no threats of death or concentration camps, but still they remained at Hadamar to continue killing "life unworthy of life." The official transcripts of the Hadamar Trial also revealed that the people in the town of Hadamar knew what was going on at the asylum and accordingly, the killing was halted for that reason in August 1941. Killings quickly resumed again in September 1941. The doctors and nurses who presided over Hadamar, it quickly comes to light, showed no remorse and felt that they had done nothing wrong. "You can ask all my patients," said one defendant. "He did not suggest, however, how one questioned the

\footnotetext{
${ }^{3}$ United States Holocaust Memorial Museum. "The Hadamar Trial." www.ushmm.org/wlc/en/article.php?Moduled=10007265, accessed on December 2, 2010.

${ }^{4}$ Nurse Huber eventually received an additional 8-year sentence from the Germans in 1947, but was granted amnesty in 1952.
} 
dead" (Green 409). The Hadamar physicians claimed they did nothing wrong and were simply following the rule of law (Schein der Legalität). The jail terms and death sentences that were handed down proved that the outside world saw these Hadamar physicians and staff as murderers who acted of their own free will.

During the Hadamar Trial, many of the doctors and nurses involved in euthanasia (of the mentally and physically ill and later Jews) claimed they only did what they were told. They feared for their jobs and their lives. According to Robert N. Proctor, “...Physicians claimed that if they had disobeyed orders, then they themselves might have become victims. There is, however, little evidence that physicians ever refused to participate in Nazi program; those few who did (in the euthanasia operation, for example), do not seem to have suffered for their refusal" (Proctor 220). However, few doctors refused to participate. There is mention of nurses who refused to participate in the actual killings that went on at Hadamar, but they continued to work at the asylum, completing other tasks such as cooking, cleaning, and laundry. While people did complain about their positions at Hadamar and requested transfers, they themselves almost never took the initiative to leave or find other work.

In addition to claiming that they were only following the court's orders, many of the doctors, including those from Hadamar, who came to stand trial after World War II were found to have lied on the stand:

\footnotetext{
"At Nuremberg, Viktor Brack swore under oath that no handicapped Jewish patient died in the euthanasia killing centers. He lied. Karl Brandt also lied at Nuremberg, claiming that he knew nothing about the fate of handicapped Jews. Physicians involved in the killing of handicapped Jews--Herman Pfannmüller, for example--also lied when asked about their Jewish patients. All these lies were part of an elaborate scheme to falsify the record. And the liars succeeded at Nuremberg and thereafter, in deceiving prosecutors, judges, and historians. Even today, their lies continue to circulate and to obscure our understanding of the fate of the handicapped Jews. But the murder of handicapped Jewish patients--which began about a year before the mass
} 
murder of Jews commenced in the occupied Soviet Union--formed an important link between euthanasia and the final solution." (Friedlander 263)

Friedlander dramatized Brack's testimony and reiterated that Brack lied about the people who lost their lives at Hadamar. Brack lied to save himself and to preserve all the files that he and others involved in the EP/OT4 falsified in order to save face. Friedlander was unable to move on from the lies, but made the link between the EP/OT4 and The Final Solution. Friedlander viewed the untruthful testimony of people such as Viktor Brack as words that allowed them freedom of guilt in the murder of handicapped Jews. The corpses and lists left behind by the Nazis contradicted the testimony of people like Brack and did not, as Friedlander believed, sully the world's understanding of what happened to handicapped Jews at facilities like Hadamar.

Lies aside, the world is now very much aware of the atrocities that occurred at Hadamar and the other euthanasia centers that were running in Germany during World War II. The Hadamar Trial gave survivors and the families of the victims a chance to confront the defendants and learn the brutal fate of their family members. The Hadamar trial also opened a new door in the area of medical ethics and bioethics, a field that had hitherto been almost non-existent. The situation at Hadamar and its sister facilities did, however, gave rise to changes in medical research and practices and still used today. 


\section{CHAPTER 2}

\section{i. ZWANGSSTERILISATION OF THE MENTALLY ILL}

The arguments surrounding Zwangssterilisation or forced sterilization are varied and range from ethics and religion to what benefits medical science. For the Nazis, the clearest argument in favor of Zwangssterilisation was the ethic of utility. The Nazis were able to manipulate even ethics and turned utility, the greatest good for the greatest number, into the greatest good for the Reich. In the purported injustice of Zwangssterilisation, the Nazis were able to justify or support their laws, the Gesetz zur Verhütung erbkranken Nachwuchses, based on the pseudo-science of eugenics. With this pseudo-science and a twisted sense of utility, the Nazis managed to sterilize a massive work force quickly and against their will.

The Nazis, however, were not the first group to employ eugenics against those deemed to be detrimental to the community. The United States courts and mental institutions also participated in sterilizing incarcerated criminals and individuals deemed to be mentally retarded, regardless of incarceration status. While it is not ethical to sterilize a person against his/her will, in the most serious cases of mental illness, it is in times of war perhaps the most utilitarian response.

Utility was the Nazi scapegoat during World War II, used to justify the forced sterilization of Jewish workers, the mentally ill, physically disabled and those considered to have or be carriers of "hereditary illnesses--congenital feeblemindedness, schizophrenia, mania, depression, epilepsy, Huntington's chorea, hereditary blindness, hereditary deafness, grave bodily malformation, alcoholism, and promiscuity" (Lifton 25). The Nazis termed people who belonged to these groups Erbkrank, which means 
"hereditarily ill." The Nazis considered the people who suffered from the aforementioned illnesses to be Lebensunwertesleben or "life unworthy of life/living." This stigmatic title led to the forcible sterilization of this population and also led to the expansion of Aktion T-4 into the Final Solution.

As in most medical situations, the ethical ramifications of one's actions are important considerations. Sterilization against a person's wishes is not ethical, but in dire cases it can be in their best interest and in the best interest of the community around them. Thus goes the argument for the ethic of utility. This utilitarian argument is an argument for the social ethic and the best interest of the community (Gemeinschaft). However, in considering the social or community ethic, personal ethics must also be analyzed. Personal ethics may dictate that Zwangssterilisation is wrong, but often the community ethic of utility supercedes personal ethics. The Nazis not only used the argument of utility for the community in the case of sterilization. They also used this rationale to justify and to implement Aktion T-4 (the EP/OT4), Aktion Reinhard (killing of prisoners in eastern Europe), and eventually to carry out the Final Solution. While skewed, the Nazi ethic of utility provides an excellent example of how the Nazis perverted an ethic set in place to protect in order to justify destruction of human life. The so-called rationale is simple: it costs the Reich "x" amount of Reichsmarks to keep each of these unworthy lives housed, fed, and medicated. By sterilizing the Erbkrank (and eventually wiping them out all together), the community can prevent the emergence of another burdensome generation of idiots, alcoholics, and others who dirty the Aryan race. The elimination of the Erbkrank, Hitler believed, would give the Aryan race even more invincibility and give rise to the eternal Reich that he envisioned (Aly). The 
mathematical and economic reasoning of the Nazis, while practical and unfeeling, eventually led from sterilization to euthanasia and then to The Final Solution.

Specifically, the Gesetz zur Verhütung erbkranken Nachwuchses vom 14. Juli 1933 laid the initial groundwork for the Nazi justification of forcible sterilization. The law set forth on July 14, 1933 named exactly the types of hereditary illnesses deemed unacceptable in addition to how cases were to be dealt with. Every major Landkreis (county), established a Hereditary Health Court composed of board certified psychiatrists and physicians, in addition to Nazi staff and judges. This board reviewed each case individually and a decision to sterilize (and eventually kill) was made quickly. As with euthanasia, people could appeal the board's decision, but reconsideration was rare. Even more rare was an overturned verdict.

The Gesetz zur Verhütung erbkranken Nachwuchses vom 14. Juli 1933, signed by Reichskanzler Adolf Hitler, Reichsminister des Innern Frick, and Der Reichsminister der Justiz Prof. Dr. Gütner was the most important document concerning the EP/OT4. This document provided the initial legal means to deprive many Germans of their right to reproduce. The extreme vocabulary used in the Gesetz zur Verhütung erbkranken Nachwuchses demonstrates the seriousness with which the Nazis dealt with citizens considered to be Erbkrank. People with hereditary illness, Erbkrankheiten, faced required internment in Kranken-, Heil- or Pflegeanstalt and should they be particularly difficult, in a Strafanstalt, or place of punishment.

We must also consider the utilitarian value of Zwangssterilisation, leaving emotion out of the process. The Nazis emphasized the burden the mentally ill placed on their families and communities. To prevent further burdensome offspring, to save 
families the expense, to prevent trauma to the patient, the family and the community, forced sterilization was often the only solution. The burden of a mentally ill family member is doubled when an equally or more seriously ill child is brought into the world. While the ethic of utility is meant to provide the greatest good for the greatest number, the Nazis took this idea a step further--from institutionalization, to sterilization, to starvation and torture, ending in murder--to include within the greater good, a eugenic hypothesis that could potentially benefit society. ${ }^{5}$ While the Nazis took utility to the extreme, there was a somewhat sympathetic forethought in Zwangssterilisation. This, all in the name of utility: the greatest good for the greatest Reich. After the war, the many trials of those who participated in the sterilizations and ensuing euthanasia produced few explanations and fewer reasons. Eventually very little guilt was found. Using utility practically and wisely is something to aspire to and while the Nazis ended up murdering millions of people, in the very beginning they appeared to have the best interest of the Reich in mind.

The twisting of the ethic of utility made forcible sterilization a viable option for the Nazis. The treatment of the people who were subjected to sterilization lacked respect and care, and many died as a result of the sterilizations themselves. Radiation treatments rendered men sterile, which was more or less harmless and had few, if any side effects. Women, on the other hand, were subjected to tubal ligations and many died as a result of

\footnotetext{
${ }^{5}$ It has been proven that controlling the reproduction of a race does nothing to hinder the birth of children with hereditary illnesses and in fact can do more damage than good. Eventually whole families are wiped out and those left, over generations, begin to intermarry and restart the process of hereditary illness because of the degree of relation.
} 
this invasive procedure. ${ }^{6}$ The United States Holocaust Memorial Museum states that many of those who were sterilized were between the ages of twenty and forty, living in psychiatric facilities and equally divided between males and females. Many of those who were sterilized were Aryan Germans. Additionally, Gypsies, Jews, homosexuals, and the spawn of French troops stationed in Germany after World War I were added to those deemed unworthy of reproduction and eventually unworthy of life. Utility may not have been completely evil, but it was the first step on the way to euthanasia and the beginning of the slippery slope on the way to mass murder.

\section{ii. EUGENICS AND STERILIZATION CASES IN THE UNITED STATES}

Eugenics is a difficult topic as it is not considered a science, at the very most, a pseudo-science. Eugenics is the human and societal application of Darwin's theory of survival of the fittest, aided by sterilization and euthanasia, to cleanse a race of people of the illnesses and deformities that make it weak. Getting rid of the weaknesses eugenics argues, will provide the race with physical and mental superiority.

Eugenics began in the late 19th century in the form of social Darwinism, which is nearly synonymous with eugenics. The Nazis used Social Darwinism and the struggle for existence as a justification for governmental actions including Zwangssterlisation and the EP/OT4. Eugenics, however, was not unique to Nazi Germany. The United States began eugenic research at the beginning of the twentieth century and later Nazi ideas of racial cleansing grew out of it (Weindling 643-649).

\footnotetext{
${ }^{6}$ The United State Holocaust Memorial Museum indicates that several thousand sterilization victims died as a result of this procedure. Women died disproportionately because of the higher risks associated with surgical procedures.
} 
Eugenics in the early twentieth century was as popular as stem cell research is

today. Eugenicists were looking to rid the human race of the illnesses that make it weak.

Adolf Hitler avidly read the works of the eugenicists and twisted the ideas to fit his own

dream of an indomitable and genetically superior race:

"Themen der Erbbiologie und Eugenik, der Sorge um die Erbgesundheit, waren in den zwanziger Jahren ähnlich populär wie heute die Nachrichten aus den Labors der Genforscher. Überall, in Europa wie in den USA, waren Wissenschaftler erstmals systematisch dem Ursprung von Erbkrankheiten auf der Spur. Rassenforscher fahndeten im europäischen Völkergemisch nach womöglich noch unverfälschten "fälischen," "ostischen," oder "dinarischen" Urtypen. Kriminologen studierten die Familienstammbäume von "Gewohnheitsverbrechern" oder vermassen die Schädelformen Krimineller, in der Hoffnung, Hinweise auf eine "asoziale Veranlagung” finden zu können. Wie ein Zerrspiegel reflektierte Hitlers Buch das gelehrte Durcheinander, ein explosives Gemisch aus Biologie und Politik, das schon lange vor dem Ersten Weltkrieg begonnen hatte, die Atmosphäre in Europa zu vergiften.

"Selektion" etwa, jener Terminus, der später auf der Rampe von Auschwitz zum Schreckenswort und zur Chiffre für den Holocaust wurde, war bereits im Werk des genialen britischen Naturforschers Charles Darwin (1809 bis 1882) zu einem gefährlich schillernden Schlüsselbegriff geworden."7

This article proves that eugenics was not a product of National Socialism, but a continuation of Charles Darwin's theory of survival of the fittest. The eugenics movement started in the United States in the 1920s. United States physicians wished to determine whether or not asocial inclination and criminality were hereditary. Hitler and his staff believed that proving asocial problems and criminality hereditary would make sterilizations and euthanasia more palatable to the Reich. Forced sterilizations and eventually euthanasia were not ideas unique to the Nazis, but a continuation and adaptation of a eugenics movement that started across the ocean.

\footnotetext{
7 "Reine Rasse--Gendiagnostik, Konen, Sterbehilfe: Wenn Wissenschaftler den Fortscritt feiern, lösen sie auch heftige Abwehrreflexe aus. Denn die Errinerung an die Euthanasie-Mordaktionen der Nazis bleibt wach.” von Klaus Frank for the magazine SPIEGEL Spezial: Das Magazin zum Thema Die Gegenwart der Vergangenheit Die Spiegel-Serie Über den Langen Schatten Des Dritten Reichs (2001).
} 
In the United States there were several important cases involving eugenic determinations that caused the sterilization of two women. The case from the Virginia State Colony for Epileptics and Feeble Minded involved a woman named Carrie Buck (Buck vs. Bell, 274 US 200 1927). ${ }^{8}$ This case upheld a statute instituting forcible sterilization of the unfit, including the mentally retarded "for the protection and health of the state." This was a clear endorsement of eugenics as a means to justify violating the 5th and 14th Amendments to the United States Constitution.

The 5th Amendment to the US Constitution guarantees the Rights of Persons, meaning that it protects against abuse of government authority in a legal proceeding or trial. Additionally, the $5^{\text {th }}$ Amendment guarantees equal protection under the law. The violation occurred when people were denied the right to procreate. The right to procreate is protected by due process clauses in both the 5th and 14th Amendments. The 14th Amendment to the US Constitution states that all men are created equal and that no one shall be denied equal protection under the law or due process. The violation of the 14 th Amendment occurred because not all people with the same illness, i.e. mental illness, were treated in the same way. Equal protection under the law means that all people must be treated in the same manner, both in every day life and in legal proceedings. There is no exception to this law. The violations of the $5^{\text {th }}$ and $14^{\text {th }}$ Amendments were acceptable during this period of time because the eugenics movement was powerful and people believed that their actions were utilitarian.

Carrie Buck, it was claimed, had a mental age of nine years old and was born to a mother who had a claimed mental age of eight years old. Carrie Buck was considered to

\footnotetext{
${ }^{8}$ http://caselaw.lp.findlaw.com/cgi-bin/getcase.pl?court=US\&vol=274\&invol=200
} 
represent a "genetic threat to society," which runs counter to the $5^{\text {th }}$ and $14^{\text {th }}$ Amendments to the United States Constitution (Appendix CI). This case violated Ms. Buck's due process right of adults to procreate and her right to equal protection under the law because not all similarly situated adults were being forcibly sterilized. Though Ms. Buck's rights were violated, Oliver Wendell Holmes, Jr., who wrote the Supreme Court decision, and the other judges agreed that the sterilization did not violate Ms. Buck's right to due process because sterilizing her would prevent another "defective" person from sullying the genetic pool by procreating (Buck v. Bell 274 U.S. 200 1927). This opinion was a clear endorsement of eugenics.

The opinion in this case was written by Oliver Wendell Holmes, Jr. (Taft, Van Devanter, McReynolds, Brandeis, Sutherland, Sanford and Stone assenting, Butler dissenting), whose argument is clearly one in favor of eugenics: "It is better for all the world, if instead of waiting to execute degenerate offspring for crime, or to let them starve for their imbecility, society can prevent those who are manifestly unfit from continuing their kind" (Buck vs. Bell, 274 US200 1927). The Buck vs. Bell decision shows how influential the pseudo-science of eugenics had become by the late 1920's. Justice Holmes realized that he was preventing the justice system from wasting money on repeat offenders and their potentially sub-eugenic offspring. What Justice Holmes and his colleagues could not see is that arbitrary sterilization, when in the wrong hands, can tumble out of control in a bad direction. The effect of Buck vs. Bell was to legitimize eugenics and in turn led to forcible sterilization laws in the United States.

In 1942, the Skinner vs. Oklahoma case attacked the sterilization laws in the US and while unable to have them overturned, it succeeded in discouraging forced 
sterilizations. Sterilizations, however, continued in the US until 1981 when the State of Oregon performed the last legal forced sterilization of a mentally ill individual. The ruling justice in the case, Justice William O Douglas, rails against the injustice of the Buck vs. Bell ruling and concludes: "[S]trict scrutiny of the classification which a State makes in a sterilization law is essential, lest unwittingly, or otherwise, individual discriminations are made against groups or types of individuals in violation of the constitutional guaranty of just and equal laws” (Skinner vs. Oklahoma 316 US 535 1942). In other words, the Skinner decision held that compulsory sterilization could not be imposed as punishment for a crime as it violated Oklahoma law. While this decision only ended punitive sterilizations, it did make lawmakers nervous. The number of compulsory sterilizations fell, and after the discovery of the Nazi eugenic cleansing inspired by American eugenics, compulsory sterilizations and eugenics in general, lost almost all public support by the 1950's.

The United States had many states in which forcible sterilization was law, including Indiana, the first state to ratify mandatory sterilization for the mentally handicapped, as well as California and Washington. In the 1970s, under the leadership of Richard M. Nixon, the United States increased funding for Medicaid-funded sterilization of low-income Americans, a program which targeted Americans of color. While these sterilizations were voluntary, later evidence shows that the Americans who were sterilized were often uninformed or misinformed about the procedures they were undergoing. ${ }^{9}$

\footnotetext{
${ }^{9}$ http://civilliberty.about.com/od/gendersexuality/tp/Forced-Sterilization-History.htm
} 
These days, most Americans are completely unaware that the United States was involved in eugenics or forced sterilization, that our country must claim a small portion of the responsibility for the Nazi eugenic laws. This is not to say that Americans have no responsibility for how the Nazis handled the discovery of American eugenics laws. However, thanks to a report on Anderson Cooper 360 on March 8, 2012, the American public is aware of forced sterilizations in California and the reluctance of the state to pay the victims reparations. ${ }^{10}$ In modern-day cases, sterilization or chemical castration is often recommended for sexual offenders. It is believed that lacking the facility to reproduce will lower the possibility of recidivism. However, studies show that the rate of recidivism drops not with sterilization or chemical castration, but with monitoring through the probation and parole departments and through extensive, behavior modification and intense therapy. ${ }^{11}$

Forcible sterilization and eugenics are just two of the mechanisms that the Nazis employed during World War II to strengthen the Third Reich. They felt that the strength of the German people was contingent upon a pure gene pool. Sterilization through eugenics merely eliminated people who were unable to defend themselves. While forcible sterilization may have a limited place in our society, they must be strictly scrutinized and regulated. On the other hand, eugenics has no place in society and remains a pseudo-science with no value except in an historical context.

\footnotetext{
${ }^{10}$ Video from Anderson Cooper 360 on CNN: ac360.blogs.cnn.com/2012/03/08/video-sterilizationvictims-seek-compensation/?hpt=ac_t60

${ }^{11}$ The Counseling and Psychotherapy Center, Inc. Proposes a containment model based on studies they have conducted that indicate recidivism is lowered through therapy, monitoring, self realization and education. The writer is a former employee of this company. www.cpcamerica.com
} 
As the leading U.S. state in eugenic sterilizations, California eugenicists sent a book on eugenics to the National Socialists well before Adolf Hitler came to power, not knowing the impact this exaggerated Social Darwinism would have on history. ${ }^{12}$ The general idea of eugenics, to perfect the human race, is a noble idea, but in practice prunes those who are sick, deformed, or suffering from a hereditary disease. Eliminating the hereditarily ill by either forced sterilization or euthanasia, is not the answer to strengthening a society. What the world learned from exaggerated Social Darwinism is that perfecting a race through eugenics and euthanasia leads to murder and war. The Nazis let their desperation for racial superiority and world domination run out of control, and the EP/OT4 and eventual Final Solution, end the lives of many human beings.

\footnotetext{
${ }^{12}$ Edwin Black, Eugenics and the Nazis—the California connection in the San Francisco Chronicle on November 3, 2003 and Timothy F. Murphy and Marc Lappe, eds. Justice and the Human Genome Project 1994: p. 18.
} 


\section{CHAPTER 3}

\section{i. THE EUTHANASIA PROGRAM (EP/OT4)}

Das Schriftstück mit Datum vom 1. September 1939 bestand aus sieben getippten Zeilen und nur einem einzigen Satz. Für Zehntausende Deutsche Kam der formlose Wisch einem Todesurteil gleich.

'Reichsleiter Bouhler' und Dr. med. Brandt', so der Text, ,sind unter Verantwortung beauftragt, die Befugnisse namentlich zu bestimmender Ärzte so zu erweitern, dass nach menschlichem Ermessen unheilbar Kranken bei kritischster Beurteilung ihres Krankheitszustandes der Gnadentod gewährt werden kann.' Unterschrift: Adolf Hitler.

....Das Schreiben, auf einem Privatbriefbogen Hitlers, erteilte den beiden Adressaten den Auftrag, die systematische Vernichtung aller unheilbar Geistesgestörten zu organisieren.

In der Berliner Tiergartenstrasse 4 etablierten Brandt und Bouhler unverzüglich eine ,Euthanasie' -Zentralstreele (nach der Anschrift ,T4' genannt), in der ein Ärztekollegium Patienten-, Meldebögen' entwarf, die an alle Heil- und Pflege-anstalten versandt wurden. Anhand der Formulare, die Fragen nach Art und Dauer des Leidens, aber auch nach ,Rasse' und Vorstrafen des Patienten enthielten, sollten ärztliche Gutachter später die Todeskandidaten unter den Kranken ermitteln. ${ }^{13}$

Euthanasia is a unique term that permeates history, though due to World War II, it is inseparable from the term genocide. Euthanasia is today most thought of in the realm of Dr. Jack Kevorkian: in the case of terminally ill patients who wish to exercise their right to die. The word euthanasia comes from the Greek euthanasia, an easy or happy death, from $\mathrm{eu}$-good, plus thanatos, death. In this thesis, however, euthanasia describes Aktion T-4, named because the orders were issued from Tiergartenstrasse 4 in Berlin (hereafter EP/OT4), intended to euthanize all Lebensunwertesleben-life unworthy of lifeso as to prune the canker from the German race and to spend the Reichsmarks instead on

\footnotetext{
13 "Reine Rasse--Gendiagnostik, Konen, Sterbehilfe: Wenn Wissenschaftler den Fortschritt feiern, lösen sie auch heftige Abwehrreflexe aus. Denn die Errinerung an die Euthanasie-Mordaktionen der Nazis bleibt wach." von Klaus Frank for the magazine SPIEGEL Spezial: Das Magazin zum Thema Die Gegenwart der Vergangenheit Die Spiegel-Serie Über den Langen Schatten Des Dritten Reichs (2001).
} 
healthy women and families whose men were fighting for the Third Reich (see Appendix A, 1939).

The traditional definition of euthanasia is a mercy killing, or ending of a life painlessly when a person is suffering from an incurable disease. Definitions of the term euthanasia, whether medical, legal or religious, generally have a positive connotation, something that provides terminal patients with a graceful option for ending their lives. Mercy killing indicates that euthanasia is positive killing. Euthanasia originally meant the end of suffering for terminally ill patients, to relieve them of their pain and to put their bodies and minds at peace. Today, hospice facilities often battle with patients who wish to end their lives as quickly and painlessly as possible; however, there are few options available to suffering Americans. ${ }^{14}$ The Nazis were brilliant propagandists and managed to turn a word that provides patients relief, into a word that masked the Nazis' true intention of purifying the German race.

This idea was so perverted by the Nazis that euthanasia has often only a negative connotation, provided also by the controversial work and "mercy killings" committed by Dr. Jack Kevorkian. At the hands of the Nazis, however, unless they were in the group of people considered Lebensunwertesleben, they would have indeed had to continue suffering in the Third Reich as well.

The term "EP/OT4" is an excellent example of the Nazis' penchant for irony and euphemism. The Nazis justified the killings by claming the victims were

\footnotetext{
14 The first ever clinic for doctor assisted suicide opened in The Netherlands this year, 2012. Their criteria for euthanasia include ".... a reoccurring voluntary request....There must be an unbearable and hopeless suffering, no alternatives anymore, and there must also be a second opinion doctor who says 'yes, this doctor is fulfilling the criteria.' And then the euthanasia or assisted suicide can be done." Walburg de Jong in article "Dutch euthanasia clinic offers mobile service" by Ben Brumfield:

http://edition.cnn.com/2012/03/07/world/europe/netherlands-euthanasia-clinic/index.html?iphoneemail
} 
Lebensunwertesleben, people unworthy of living (see Appendix A, 1940). It did not matter what family they came from, Aryan, Jew, Gypsy, as long as they were inferior and suffering from an Erbkrankheit, hereditary illness, the murders were justified. Euthanasia took on an entirely dastardly meaning during the Second World War and the Nazi penchant for euphemism and twisting language temporarily granted them time enough to end the lives of some 50,000 to 90,000 innocent men, women and children. Despite objections from clergy and townspeople, this operation continued throughout the war, officially and unofficially, ending in The Final Solution and the death of some six million Jews.

In 1939, the Reich Chancellery established the EP/OT4 under the direction of Philip Bouhler and Dr. Karl Brandt, who was Hitler's personal physician. Under the guidance of these two men, the EP/OT4 took shape and in the end, killed 80,000-100,000 adults from mental institutions, 5,000 children from care facilities, and 1,000 Jews from institutions. ${ }^{15}$ Euthanasia is most often defined (generally accepted definition) as a "mercy killing," and in naming the program such the sadistic Nazis were not only making fun of their victims, but trying to outwardly justify the actions of the program.

The EP/OT4 was brought to life as a result of the Nazi ideals concerning a pure, strong, and impregnable Aryan race. The Third Reich was committed to removing those whose lives they deemed unworthy of living and giving the resulting resources to healthy Aryans who would repopulate the Reich with more healthy, strong, Aryan children. This

\footnotetext{
${ }^{15}$ Numbers from Robert J. Lifton in his book The Nazi Doctors Medical Killing and the Psychology of Genocide, do not include those who were killed in 14f13, the prisoner/invalid killing program initiated at concentration camps from 1941-1944. Eventually this program morphed into Aktion Reinhard where the extermination of all concentration camp internees began.
} 
idea was made into law in 1935 and began with forcible sterilizations for those who were deemed Lebensunwertesleben (see Appendix A, 1938). ${ }^{16}$

At first the victims were gassed in specially designed vans, but as public outcry prevented this obvious form of murder, victims were given lethal injections and/or starved to death. The timeline for the gas vans, as presented by Mitchell G. Bard at the Jewish Virtual Library, explains that between mid August of 1941 and late November and early December of the same year, the idea was seeded by Heinrich Himmler, researched, tested, and implemented (see Appendix A, 1941). The gas van was a unique way to kill larger numbers of people at one time and the idea was developed on a much larger scale during the Final Solution:

\begin{abstract}
Die Suche nach einem praktikabeln Tötungsverfahren beendete Brandt mit einem Experiment. Anfang 1940 resite er mit seinem T4-Stab in die Heilanstalt Brandenburg an der Havel, wo er und er Reichsärzteführer Leonardo Conti sechs Patienten mit Hilfre tödlicher Injektionen ums Leben brachten. Acht weitere wurden in einen bunkerähnlichen Raum geführt; nachdem die Türen verriegelt waren, liessen Helfer über ein Rohrsystem Kohlenmonoxid in das Verlies strömen.

Am Ende des schauerlichen Vergleichstests wusste das T4-team, wie es sich entscheiden würde: für die Gaskammer. Bald schon rollten graue Busse mit verhängten Fenstern durchs Land, die Gruppen von Kranken und geistig Behinderten in eigens geschaffene Tötungsanstalten transportieren. ${ }^{17}$
\end{abstract}

These killing vehicles were airtight and mounted on a chassis, and were obviously mobile. They killed people by attaching the motor exhaust pipes inside the van and then turning the engine on. Victims first became unconscious and then quickly suffocated. Those who did not succumb immediately to the carbon monoxide gas were shot. As the

\footnotetext{
${ }^{16}$ The 1935 law includes those who suffered from "hereditary diseases" and those who were from "inferior races," such as Jews and Gypsies, Aryans who suffered from mental disease or were severely disabled, the insane and the terminally ill, though Aryan, were also part of this group. Please see Appendix CI.

17 "Reine Rasse--Gendiagnostik, Konen, Sterbehilfe: Wenn Wissenschaftler den Fortscritt feiern, lösen sie auch heftige Abwehrreflexe aus. Denn die Errinerung an die Euthanasie-Mordaktionen der Nazis bleibt wach.” von Klaus Frank for the magazine SPIEGEL Spezial: Das Magazin zum Thema Die Gegenwart der Vergangenheit Die Spiegel-Serie Über den Langen Schatten Des Dritten Reichs (2001).
} 
Nazis had a penchant for euphemism, these vans were called Sonderwagen,

Sonderfahrzeug, or Spezialwagen. These names, and the words sonder and spezial indicate that these were "special" trucks, which was a positive connotation that may have helped alleviate guilt and temporarily prevent outsiders and civilians from understanding what kind of crime the vans and their controllers were committing. The words sonder and spezial change the meaning of the Wagen and Fahrzeug and gives no reason for a witness to think that the cars and vans had a use other than transporting goods. These words, sonder and spezial gave citizens of the Third Reich no reason to question the vans' use and also presented a sense of normalcy in the midst of war. The Nazis twisted these words, and their secret meaning indicated a quick mercy death via gassing in the back of a van, for all those the Nazis considered Erbkrank or Lebensunwertesleben. Nazi propaganda was the perfect cloaking device, a linguistic device that protected their many secrets.

After the use of the gas vans became obvious to the people in the areas surrounding Hadamar and the linguistic propaganda evaporated, Hitler ordered the gas vans be phased out, dismantled and sent into the eastern parts of Europe: "Hitler liess die T4-Aktion nach Protesten aus Kirchenkreisen im August 1941 stoppen. Doch auch danach ging das Morden, insgeheim, weiter" (Franke, 133). Michael Burleigh tells of villagers in Hadamar seeing the buses transporting asylum inmates to Hadamar and knowing their fate. Children often joked that misbehaving would result in being burned in the ovens at Hadamar (Burleigh, 142-149). There was also outcry from the church. Bishop Clemens August von Galen publicly spoke out against EP/OT4 in a sermon and indicted the Nazis as murderers who had decided to play G-d. At this point in time, in 
1941, the Nazis temporarily halted the EP/OT4 because of protests like that of von Galen. The EP/OT4 restarted again in October of the same year with an expanded list of those to be euthanized (see Appendix A, 1941).

The gas vans, as a new killing mechanism, were more ruthless as they involved actual contact with the victims. Victims were either starved to death or were given lethal injections of strong narcotics and anesthetics. Once these killing mechanisms were set in place, victims were transferred from non-killing facilities to places like Hadamar, where they were either killed immediately with an injection or had their rations reduced so drastically that they died of starvation/malnutrition within only a few weeks. The few who survived describe eating tree bark, straw from their mattresses, and leaves in order to survive. The food rations of the Erbkrank and Lebensunwertesleben, went from hearty soups with meat to watery turnip soups, no protein and only the occasional potato. ${ }^{18}$

The Nazis employed rationing with the rationalization that mothers, children and soldiers outside the asylums were starving to death in German cities and that asylum inmates were undeserving of full. In their view, inmates were of no value to the Reich and deprived worthy Germans of resources including rations and medicine.

EP/OT4 during the Third Reich did not begin in Germany. Hans-Heinrich Wilhelm writes that the first large-scale euthanasia took place in Pomerania and eastern Prussia after the start of the Nazis' Polish campaign (see Appendix A, 1939). ${ }^{\mathbf{1 9}}$

\footnotetext{
${ }^{18}$ Burleigh, Michael: Death and Deliverance Euthanasia in Germany 1900-1945, 229.

19 "The Euthanasia Program" in The Encyclopedia of the Holocaust, Vol. II, pp. 452-454, from an article from the Jewish Virtual Library.
} 


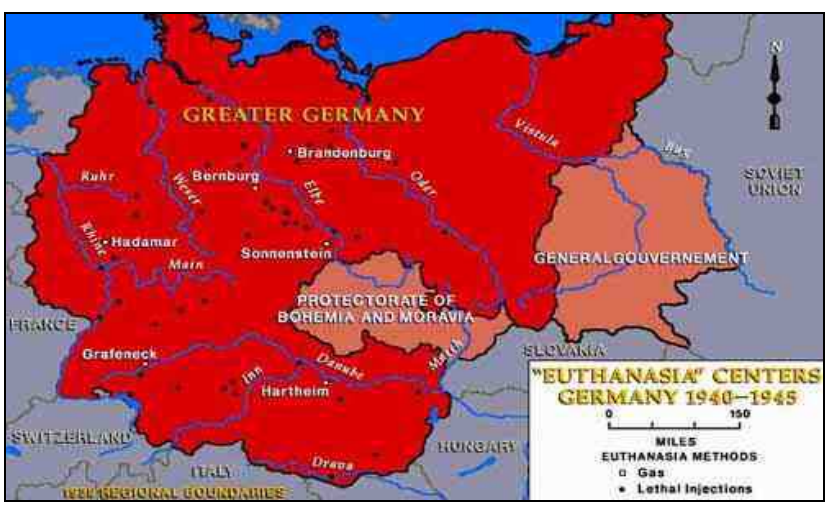

Figure 1 Euthanasia Program in Germany 1940-45 (Jewish Virtual Library)

The year 1940 saw four euthanasia centers open in Germany between January and June: Grafeneck (January), Brandenburg (February), Hartheim (May) and Sonnenstein (June). It is estimated that 8700 people were gassed in these facilities in the first half of 1940 alone, most in May and June (see Appendix A, 1940). By the end of the same year, approximately 26,500 people had been murdered and by August 1941, 35,100. These were the first official statistics to come from Tiergartenstrasse 4 with regard to EP/OT4 and its success. More killing centers were added as the war continued as the Nazis continued to weed out the mentally ill, Erbkrank, and Lebensunwertes Leben in order to continue cleansing the German race. In 1939 the Nazis continued EP/OT4 at Bernburg, Brandenburg, Grafeneck, Hadamar, Hartheim and Sonnenstein. These killing centers were located in different parts of the Reich in order to service all parts of the country and avoid the difficulties in transferring victims to and from other centers.

As became the norm later in the concentration camps, EP/OT4 physicians selected victims who were to be transferred from one facility to another. This was a mostly arbitrary action with little consultation of medical files. Medical files were primarily used to soothe families whose loved one died suddenly. Falsified medical files erroneously indicated a sudden illness that resulted in a speedy death. Michael Burleigh 
indicates that physicians at places like Hadamar had lists of sixty-one (61) possible causes of death. The causes were chosen based on the victim's age, sex, and general health before they were gassed (Burleigh, 147). Upon receiving "faked death certificates [and] standardized letters of condolence," family members would occasionally write back to the psychiatric facilities demanding to know how a loved one died of a burst appendix, for example, when the appendix removal had happened many years previously. ${ }^{20}$

Occasionally male ashes would arrive with hairpins, leading family members to ask if a mistake had occurred and upon receiving a vague answer, they began to feel that the circumstances of death were a bit mysterious. ${ }^{21}$ Despite appearing to have ended the EP/OT4, in fact, the killings continued, but in a less obvious way, until the end of the Second World War.

The EP/OT4 not only ended the lives of those the Nazis considered unworthy of living, but also was an obvious precursor to The Final Solution. Many of the staff from Hadamar and other killing centers were eventually sent to the eastern part of Europe and became concentration camp blockovas, capos, and leaders. The transfer of staff from the EP/OT4 to Aktion Reinhard, also know as The Final Solution, was a direct result of the 1942 Wannsee Conference. In the article "The T-4 Euthanasia Program," Mitchell G. Bard relates the experiences of SS Major Christian Wirth, who left one of the euthanasia centers in Germany to take over at Chelmno, an extermination camp in Poland. Major Wirth already had extensive experience in committing crimes against humanity by

\footnotetext{
${ }^{20}$ Michael Burleigh writes that letters were written back to Hadamar, specifically. These letters no longer exist at the Hadamar archives at the Memorial itself or in the state archives in Kassel.

21 Michael Burleigh writes that ashes of males arrived with hairpins, but no record of the outrage or confusion is documented in available archival documents.
} 
organizing genocide at an EP/OT4 killing center in Germany. Wirth's successful career continued at Belzec, Treblinka, and Sobibor. His appointment at these Final Solution killing centers, are a confirmation of EP/OT4 as the precursor to the Final Solution. Another SS member and veteran of EP/OT4 who was a successful perpetrator of genocide was Franz Stangl. Stangl was also transferred from a German euthanasia center to Sobibor, where he became the camp commander. His positive performance resulted in a 1942 transfer to Treblinka. Stangl was found guilty of "joint responsibility for the murder of 900,000 Jews" as part of the Final Solution.

Stangl and Wirth are examples of Nazis who were able to bring euthanasia from small psychiatric facilities to large killing facilities. Their experience in EP/OT4 made it easy for them to send even larger groups of people to their death. EP/OT4 was a paradigm for the larger genocide of World War II, from killing only the Erbkrank and Lebensunwertesleben to killing all those considered to be inferior. EP/OT4 was the impetus for the Final Solution. The program created by the Nazis to relieve the Reich of Lebensunwertes Leben and Erbkrankheiten metastasized and became the way to murder massive groups of people in a short period of time.

At the end of the Second World War, EP/OT4 leader Viktor Brack was arrested and put on trial for, among other things, crimes against humanity and general war crimes. Brack was interrogated during his trial and while on the stand, Brack explained the methods used to murder the EP/OT4 victims, though the prosecutor called them "mercy killings," Brack went on to explain the function of the gas vans and their carbon monoxide toxicity. Brack elaborated on the wishes of Bouhler (his superior), including the fact that Bouhler required the deaths to be painless and imperceptible. Brack's point 
in describing the wishes of Phillip Bouhler was to prove that the killings he carried out were indeed merciful in their painlessness. Whether or not the painlessness was really Bouhler's wish is no longer relevant, but it may have been his only redeeming quality.

Brack testified that the victims were photographed before they entered the gas vans, and eventually gas chambers, which they were told were showers. Twenty to thirty victims were gassed at a time, the gassing being executed by the doctor in charge of the euthanasia center. Brack's testimony also described the post-gassing events, which included cleaning of the gas vans/chambers (depending on the facility), post mortem examinations of the deceased, and eventually cremation and release of remains to family members. Brack related that every euthanasia center had its own crematorium. Many of the crematoria were dismantled and moved to Poland in 1941 after Hitler temporarily ordered the gassings to cease. The dismantling and removal of the crematoria to Poland did not mean the end of euthanasia or gassings. At this time, gassings at concentration camps across Europe were being ramped up and the EP/OT4 was no longer important. Phillip Bouhler and Viktor Brack were responsible for the murder of Lebensunwertesleben. Viktor Brack was the son of a physician's assistant and after working as Heinrich Himmler's chauffeur, he joined the NSDAP and the SS in 1929. Brack floated around the highest circles within the NSDAP and eventually was promoted to be Phillip Bouhler's deputy and reached the rank of Oberdienstleiter and the Chief of Section II in the Führer's Chancellery. His position within the Führer's Chancellery as Bouhler's deputy eventually led to his involvement in EP/OT4. Oberdienstleiter Brack was responsible for the killing of the mentally ill, chronically sick and those suffering from hereditary illnesses as well as politically undesirable elements such as Communists 
and resistance fighters, Jews, homosexuals and Gypsies. Brack personally interviewed and selected personnel for the euthanasia centers. He appointed those involved in cremating the corpses to the people who cleaned the facilities. ${ }^{22}$ In 1941 Brack set up gassing facilities in Riga and Minsk to exterminate Jews, who were judged unsuitable for work. He was also closely involved in the construction of the death camps in Poland, the supplying of its personnel (often from euthanasia centers) and the dismantling and moving of the cremation chambers from the euthanasia centers, to Poland. Brack was also one of the key players in the EP/OT4 and kept the program running until The Final Solution reached full force.

Much to Brack's disappointment, Riga and Minsk lost the opportunity to house new killings centers. Brack was ready to build death camps in Poland. The Third Reich instead constructed the killings centers in the Generalgouvernement area of what is today known as Poland. Brack testified at his post war trial that his orders were to discontinue the EP/OT4 and to have his staff relocate to Lublin and answer to a man named Globocnik. Among the staff sent to Lublin to work under Globocnik was Christian Wirth. Brack, after visiting with the SS-Brigadeführer, wrote a letter to Heinrich Himmler requesting more personnel to bolster the growth of Aktion-Reinhard: in the letter, Brack tells Himmler that there are between two and three million Jews within European Jewry who are capable of working and should be spared from being gassed. Those who are able to work or those who are useable, Brack continued, should be sterilized so as not to reproduce and dirty the Reich's Aryan population. Brack returned to the idea of Zwangssterlisation in the Generalgouvernement and let Himmler know that

\footnotetext{
${ }^{22}$ Based on information provided by holocaustresearchproject.org
} 
both Bouhler's staff and physicians and the means to castrate all the workers, needed to be put in place as quickly as possible. Sterilizing the masses of Lebensunwertes Leben and the Erbkrank would prevent them from producing offspring that is eugenically inferior and would save the Reich the resources, which would be spent on feeding them. Brack adds that he has afforded Globocnik more personnel so that he could quickly address the Jewish Problem. Additionally, in order to maintain discretion and avoid problems, i.e. potential (and now inevitable) questions from Allied forces, Brack requested that Himmler approve the sterilizations as quickly as possible. Himmler replied in due haste, instructing Brack to sterilize the Jews by means of $\mathrm{x}$-rays and to call up the necessary additional staff and machinery necessary.

Brack's immediate commander was Philipp Bouhler. Bouhler was born on September 11, 1899 in Munich. Philipp Bouhler studied philosophy in Munich after the First World War. Joining the NSDAP in 1922, he rose quickly through the ranks and became one of Hitler's favorite officers and part of his inner circle. Bouhler was both Reichsleiter and the Chief of the Führer's Chancellery (Brack was Chief II of the Führer's Chancellery) and an SS Obergruppenführer to boot. He also had a major hand in the orchestration of Aktion T4. Much less is written about Philipp Bouhler than about Viktor Brack. While he was in command of EP/OT4, he had little hands on responsibility for what happened during this particular operation. Those responsibilities were mainly carried out by Brack and his immediate staff. Although Bouhler was not directly involved in Aktion T4, he was one of the two recipients of Hitler's order to start a mercy killing program in the Third Reich. The Allied Forces arrested Bouhler and his 
wife in April of 1945. He committed suicide, what some consider a selfish form of mercy killing, and was never tried.

EP/OT4 was a program designed to enhance the German race, to make it stronger and to end genetic diseases like alcoholism, promiscuity and schizophrenia. The initial desire may have been manipulated to be positive, but the end result was the mass murder of millions of people the Nazis considered to be unworthy of life. EP/OT4 was the paradigm for the Final Solution. Compulsory sterilization turned into selective euthanasia and after realizing the benefits for the Reich, selective euthanasia became widespread murder. In the end, the Final Solution was murder, the end of life for people considered too sick, too deformed, or too pathetic. The word murder, however, is not descriptive enough to express the scale of suffering leading up to death. The EP/OT4 gave life to the Final Solution and the Final Solution was genocide. This presents the possibility that as the prototype for the Final Solution, that EP/OT4 was also genocide.

\section{ii. WAS EP/OT4 GENOCIDE?}

In Samantha Power's A Problem from Hell, she describes Raphael Lemkin's journey to have the word "genocide" accepted and approved by the United Nations. Genocide did not exist as a crime until 1944, when Raphael Lemkin championed the word as an apt term to describe the atrocities committed against the Jews during World War II. His definition was approved by the United Nations on 9 December 1948. The Convention on the Prevention and Punishment of the Crime of Genocide calls genocide 
an international crime that should be prevented and punished by all United Nations countries. The Convention defines genocide as:

[G]enocide means any of the following acts committed with intent to destroy, in whole or in part, a national, ethnical, racial or religious group, as such:

(a) Killing members of the group;

(b) Causing serious bodily or mental harm to members of the group;

(c) Deliberately inflicting on the group conditions of life calculated to bring about its physical destruction in whole or in part;

(d) Imposing measures intended to prevent births within the group;

(e) Forcibly transferring children of the group to another group. ${ }^{23}$

Euthanasia clearly fulfills many of the criteria set forth by The Convention on the Prevention and Punishment of the Crime of Genocide; however, the EP/OT4 as set forth in the post war trials, was not considered genocide and the perpetrators were also not charged with genocide because the victims were not part of a specific national, ethnic, racial or religious group. The officials in charge of EP/OT4 were charged with murder and war crimes, but not genocide. Victims were of all nationalities, ethnicities, races, and religions, and indeed many of the victims were Aryan Germans. This loophole is why the court was unable to bring genocide charges against EP/OT4. There is, however, an argument for developing such phrases as "social genocide" or "medical genocide" as they are not currently used to describe EP/OT4 or any other kind of mass euthanasia

Euthanasia, however, does beg the question as to whether or not the Convention should be amended to include it among other crimes considered to be genocide. The argument to coin a new phrase allows a clear delineation between euthanasia and genocide or murder. Raphael Lemkin's crusade to have genocide become part of the crimes against humanity was brave, and while at times pedantic, it nonetheless provided tools to punish those who have perpetrated genocide. While euthanasia is perhaps neither

${ }^{23}$ A Problem from Hell, Samantha Power, pg. 57 
genocide nor a crime against humanity, it is still murder. Genocide is mass murder with previously unimagined cruelty. This unimaginable cruelty is what led Raphael Lemkin on his crusade to give mass murder a name, genocide, and have it become a crime against humanity within the United Nations.

Genocide is mass murder and leaves nothing to the imagination-gassings, shootings, stabbings all belong in this category, but euthanasia, mercy killing, does not. Euthanasia is a more nebulous term that offers the idea of mercy killing and not murder; pity and not hatred. The origin of this term was warped by war and no longer belongs under the term "genocide." Euthanasia begs its own category. Raphael Lemkin wanted to add "genocide" to the Convention on the Prevention and Punishment of the Crime of Genocide because genocide—-mass murder-was nameless and unpunishable up and until the Convention accepted the word. While mass euthanasia has a clear definition and is a punishable offense, its magnitude deserves recognition. When you euthanize a beloved pet, you are granting it mercy and ending its suffering, but the same cannot be said for World War II euthanasia victims, including those at Hadamar. The Nazi argument for mass euthanasia was utilitarian and from their point of view, financially sound, but without individual or informed consent, it was also a form of genocide.

Lemkin, who was not a scholar of EP/OT4, describes the ordeal of genocide as a "blunt wood stake driven into the base of my head" and ends his description saying that language at this point in time, was unable to adequately describe the suffering of Holocaust victims and survivors (Power, 42). When the United Nations Convention finally adopted the term "genocide," sufferers of all of history's genocides, from Armenia to the Sudan, had a word that precisely described the crime of which they were victims. 
The victims of Hadamar and facilities like it still have no term to describe the crime they suffered, though euthanasia has been condemned by the United Nations. ${ }^{24}$

As an argument in favor of adding the term genocide to the Convention, Austrian philosophy and Holocaust survivor Jean Amery commented on the lack of words to describe the ordeal that he and fellow survivors endured:
Was it "like a red-hot iron in my shoulders" and was this ,like a blunt wooden stake driven into the base of my head?"- - a simile would only stand for something else, and in the end we would be led around by the nose in a hopeless carousel of comparisons. Pain was what it was. There's nothing further to say about it. Qualities of feeling are as incomparable as they are indescribable. They mark the limits of language's ability to communicate. ${ }^{25}$

This powerful description of a lack of words to describe a Holocaust survivor's suffering equally describes the lack of words to describe the experience of being housed in a place like Hadamar. It seems that perhaps "social genocide" is a new term to be coined that can describe the elimination of a group of people based on their perceived mental and physical shortcomings. Lemkin's crusade should be renewed in order to clearly define the EP/OT4 not just as euthanasia and murder, but "social genocide" as the deliberate killing of a group at places like Hadamar because of their (perceived) mental and/or physical handicap. Raphael Lemkin went to great lengths to preserve the memory of the victims of the Holocaust and all preceding and future genocides, but left the United Nations to group genocide and the Nazi Medical Experiments in with crimes against humanity and mass murder, instead of defining euthanasia as a part of genocide or a separate crime entirely.

\footnotetext{
${ }^{24}$ The United Nations Human Rights Committee condemned euthanasia in their Consideration of Reports Submitted by States Parties Under Article 40 of the Covenant on 8/27/2001. The euthanasia during World War II, however, was not directly addressed.

25 "A Problem from Hell" American and the Age of Genocide by Samantha Power (p.42)
} 
"Social genocide" appears to have the makings of a term that the United Nations might want to consider as an addition to the Convention that includes the original term genocides and crimes against humanity in its text. Attaching a new phrase like "medical genocide" to the United Nations Convention or expanding the definition to include persons who are targeted due to their mental or physical short comings, would give these victims not only a specific crime to have suffered, but would give the world another way to define and prevent such crimes from being perpetrated in the future. "Medical genocide" or an expanded definition of genocide should include all the euthanasia victims from the Second World War, including those who were German soldiers, cast aside by their countrymen because they suffered from minor to severe forms of PTSD (post traumatic stress disorder), depression, mania, and any number of other war related mental illnesses. Many of these German soldiers were in asylums like Hadamar and suffered the same indignant death as inmates who were Lebensunwertes Leben or Erbkrank. This group of people should be given recognition for their suffering and euthanasia could perhaps return to its original meaning of painless death and mercy killing. The term "social genocide" does not yet exist in available related literature. The new addition would be another awakening to Holocaust deniers and the rest of the world that Jews were not the only victims of the Holocaust, but that Aryan Germans, German soldiers, Aryan children, the mentally ill and those suffering from hereditary illnesses experienced an equally cruel fate at the hands of physicians like those at Hadamar. This cruel fate expands the crimes of which dictators like Adolf Hitler and Pol Pot and their henchmen can be accused and convicted of. Sadly, it also gives the world another crime to fear. 
Giving the victims and the few survivors their own term or crime helps to negate the Nazi euphemism and return euthanasia to its original meaning of mercy killing. 


\section{CHAPTER 4}

\section{i. RIGHTS, JUSTICE, UTILITY AND CARE: The Ethics of Patient Care}

Ethical patient care can be broken down into four basic categories: rights, justice, utility, and care. What the mentally ill patients, "mad" German soldiers and all the other victims endured at the hands of these doctors at Hadamar was unethical, but perhaps diabolically practical. Scholars spend many hours trying to figure out what possessed so many doctors and nurses to abandon their Hippocratic Oath not to harm people. In the end, there is no real answer. Many scholars, Michael Burleigh, for example, contend that German pride, self-interest, self-preservation, and the desire to please pushed any thoughts of ethics out of the heads of doctors at Hadamar and beyond. Burleigh's point is the ideology of the invincibility of the German race worked against any thoughts of morality or ethics that lay in the minds of physicians. ${ }^{26}$ Preservation of race and the elimination of weaknesses, both real and perceived, became the ultimate goal of Zwangssterlisation and the EP/OT4 and gave no credence to potential ethical consequences and physicians believed in this Aryan cause. The consequences of ignoring ethics are not only historical damnation and a reputation for cruelty, but also a clear violation of the four tenets that combine to create the ethic of patient care: rights, justice, utility, and care.

The ethic of patient care, had it been available to the victims of Hadamar, would have addressed their physical and their mental welfare, their care, and their physical living situation. When rights are violated, a situation automatically becomes unethical.

\footnotetext{
${ }^{26}$ Death and Deliverance Euthanasia in Germany 1900-1945, Michael Burleigh.
} 
Every human being, regardless of mental state, disease, defect, race, or sex, has basic rights that should never be violated: health happiness, truth and a right to life. All of these were ignored by the EP/OT4 staff at Hadamar. Every experience that the victims of Hadamar had was a violation, a cause of pain, suffering, and a consequence of untruth. These violations of patient care were unethical and the antithesis of health, happiness, truth and a right to life.

In Michael Burleigh's book Death and Deliverance: Euthanasia in Germany 19001945, Dr. Elizabeth V. comments on the selection process at Hadamar saying that the asylum director, a doctor named Schmidt, “....seems to have acted very arbitrarily and was not free from sudden changes of mood" when making his selections for those who would die. ${ }^{27}$ This physician realized that the lives of the Hadamar patients were of no consequence to the doctors who examined them before they died. The mood of the doctor also played a large role in who died, how they died and when they died. It is evident that the medical (not psychological) examination and ensuing death was a routine process and did was not free from whim and the particular mood of the examining doctor on a particular day. These arbitrary decisions may have sent inmates capable of working (thereby benefiting the Reich) to a premature death. The whims of Hadamar physicians were another violation of the Hippocratic Oath (not to bring on an untimely death) and added to the list of crimes committed at the asylum at Hadamar.

27 Burleigh takes great care not to put last names to the doctors and nurses of Hadamar. While respecting their anonymity, he prevents justice. 
The ethic of patient care should to nurture relationships, wellbeing, and emotions.

Very few if any of the doctors and nurses at Hadamar expressed any emotional reaction to the heinous deaths they carried out. One psychiatric nurse, Irmgard Huber,

$$
\begin{aligned}
& \text { '...maintained the psychological fiction that she had nothing to do with the } \\
& \text { murders in the asylum cellars.... Although she 'suffered' because of what was } \\
& \text { happening at Hadamar, and knew that one should not kill,' Huber nonetheless } \\
& \text { became a functioning cog in the machinery of extermination. She said she } \\
& \text { could not sleep at night. She asked...for a transfer....She used various } \\
& \text { strategies of denial and evasion to distance herself from what she was } \\
& \text { doing.... The local priest [later] testified that she was desperate to leave the } \\
& \text { asylum. In her own eyes, she was thus a passive vessel, simply relaying } \\
& \text { instructions from the doctor to her subordinates." (Burleigh, 240) }
\end{aligned}
$$

While Huber had some reservations about her job as a psychiatric nurse at Hadamar, she never admitted to feeling guilt, sadness, or horror at what she was doing; she claims she merely suffered. Ms. Huber considers herself a victim because of the trauma she witnessed at Hadamar. Her thoughts are only of herself and her suffering, not taking a single moment to reflect on the lives she helped end. She, like many others, maintained that she was following orders and could not possibly have fought against her employers. While she requested a transfer, the transfer would not change her job, just the facility where she worked. Irmgard Huber never expressed any guilt for her actions and justified her job through denial and evasion, and distanced herself from Hadamar as best she could. Her guilt, however, betrayed her and manifested itself in the sleeplessness she experienced throughout her tenure at Hadamar. Her acts were unethical and devoid of caring, but in her eyes, she was doing the Erbkrank and Lebensunwertesleben a favor by allowing them to die a merciful death.

There is no possible ethical outcome in any situation when rights, justice, utility, and care are violated. The physicians and nurses at Hadamar remorselessly cast aside their morals and their Hippocratic Oath to do no harm. They believed that everything 
they did was for the betterment of the Third Reich. Before Zwangssterilisation morphed into the EP/OT4, Imrgard Huber and her contemporaries practiced war time utility which provided at least a bit of justification for depriving people of their right to reproduce and to live. ${ }^{28}$ Zwangssterilisation was the first unethical step towards EP/OT4. Murder, which is what EP/OT4 became, superceded the pretense of medicine and patient care and the utility of Zwangssterilisation and branded Irmgard Huber and her associates at Hadamar as accessories to murder.

\section{ii. Clemens August von Galen: Champion Against Zwangssterilisation}

There were champions for the victims of Hadamar and similar facilities; though few, they made sure that their voices were heard in the loudest possible manner, preaching and pontificating from pulpits across the Reich, but to no avail. The greatest champion against the euthanasia program in Nazi Germany was a Catholic bishop, Clemens August Graf von Galen (Appendix B), the Bishop at Münster. In a sermon given on August 3, 1941, von Galen pontificated on murder and how the Nazis were clearly violating God's will. Von Galen passionately commented people who are charged with bringing justice, are going against the will of God and basic human rights by sending people away to be killed by murderers who would not be brought to justice.

\footnotetext{
${ }^{28}$ Robert Jay Lifton describes the evolution that ended as the EP/OT4 and the Final Solution as having had many redundancies and changes. He goes on to describe the five steps: "Of the five identifiable by which the Nazies carried out the principle of 'life unworthy of life,' coercive sterilization was the first. There foloowed the killing of impaired children in hospitals; and then the killing of 'impaired' adults, mostly collected from mental hospitals, in centers especially equipped with carbon monoxide gas. This project was extended (in the same killing centers) to 'impaired' inmates of concentration and extermination camps, and, finally, to mass killings in the extermiatnion camps themselves." (Lifton, The Nazi Doctors: Medical Killing and the Psychology of Genocide)
} 
He demanded to know why these Nazis decided that they had the divine right to

determine who lives and dies. Von Galen received knowledge of the EP/OT4 program in

July of 1940. He attempted to lodge a complaint with his superior, Cardinal Bertram:

“...Öffentlich hatte bereits im Sommer 1941 der katholische Bischof von Münster Clemens August Graf von Galen gegen die Ermordung der Behinderten gepredigt. Der Münsteraner Bischof liess keinen Zweifel an der Absicht und den Umfang der morde, führte Zahlen auf und Namen von Anstalten, gab individuelle Beispiele und bezeichnete die Aktion als staatlich angeordneten Mord und verwies auf die moralischen und gesellschaftlichen Folgen. Gaf Galens Predigt war der erste öffentliche Protest gegen die "Euthanasie-Aktion," von der manche schon seit längerer Zeit wussten, auch die Vertreter der Kirche. Der Bischof von Münster war seit Juli 1940 informiert. Trotz intensiver Bemühungen war es ihm nicht gelungen, Kardinal Bertram, den Vorsitzenden der katholischen Bischofskonferenz, zu einem offiziellen Protest im Namen der katholischen Kirche zu bewegen. Einer seiner Berater hatte unter Hinweis auf die bedrängten katholischen Gläubigen abgeraten, denn ,,jede Unvorsichtigkeit und Überstürzung könnte sich sachlich mit weittragenden Folgen in seelsorgerlich-kirchlichen Belangen überhaupt schwer schädigend auswirken., 29

Von Galen argues in his sermon that the Nazis are not God and have no right or the power to decide who lives or dies. They were never granted divine intervention by God. The Bishop continues his sermon, admonishing his congregation and said that if it is neighbors and family members who are to decide a person's worth, there is no trust between men in a time when trust is imperative. He also makes the obvious statement that no life is safe and that life is also no longer sacred when men feel they can decide who lives or dies and whether a life has worth. Von Galen believed, with scripture on his side, that the EP/OT4 went against the teachings of God and that going against God is inherently unethical. Bishop von Galen elaborates on the questions of duty and morality in his famous sermon, Predigt von Galens zur Ermordung Behinderter and asks more

\footnotetext{
${ }^{29}$ From "Reine Rasse: Gendiagnostik, Klonen, Sterbehilfe: Wenn Wissenschaftler den Fortschritt feiern, lösen sie auch heftige Abwehrreflexe aus. Denn die Errinnerung an die Euthanasie-Mordaktionen der Nazis bleibt wach". Spiegel Special: Das Magazin zum Thema Die Gegenwart der Vergangenheit, Die Spiegel-Serie Über den Langen Schatten des Dritten Reichs. Number 1, 2001: pgs. 132-38.
} 
than once, "do we [you] have the right to decide who lives or dies?" Von Galen went on to comment on the presumed lack of productivity of the people sentenced to death in the euthanasia program and correctly assumed that he, being of sound mind and body, upon becoming elderly and feeble, would be deemed unproductive and therefore a "life unworthy of life," despite what he might have contributed to his community before age ravaged his mind and body. Bishop von Galen also took to task the religious orders for allowing such atrocities to occur and he cited the law that indicates a person who murders his brother (pre-meditated) shall himself be punished by death. While all of von Galen's arguments were valid, his speech did little to inspire his congregation to take up verbal arms against the Nazis and their euthanasia program. Bishop von Galen was a champion for his victims and his sermon proves that even if very few people were able to speak out against euthanasia, at least they were vehement. The Bishop's protests were passionate, but failed to bring his congregation to action. The inaction of von Galen's congregation indicates not only ignorance, but apathy and frustrating complacence: both reactions that permeated the war and allowed, at least temporarily, the Nazis to continue EP/OT4.

iii. The Argument Surrounding the Use of Nazi Medical Research

There are several arguments to consider when deciding whether or not it is ethical to use the results of Nazi Medical Research done in institutions like Hadamar. Baruch Cohen wrote his article, The Ethics of Using Medical Date From Nazi Experiments to address critical questions the science community faces in a changing world of medical research. Cohen wanted to find an answer as to whether or not it is ever appropriate to 
use the data from Nazi medical experiments and under what circumstances. The main problem with Cohen's argument is that he finds the plight of Jews in the Holocaust, especially those who were subjected to medical experiments, insurmountable. In citing certain Nazi experiments, Cohen inadvertently proved that the specific experiment has positively affected modern medicine, in spite of his denigration of all the experiments and their results. His faith in the Babylonian Talmud instructed him to honor the sacrifice of the Jews who died during medical experiments, Cohen was unable to come to a discernable conclusion on when and how to use the medical data from the Nazi medical experiments. $^{30}$

Cohen presents many arguments for each category of experiment conducted by the Nazis. Though he occasionally proves the research helpful, he is unable to see the research as a benefit to modern medicine. This benefit to modern medicine is one of the arguments for using the data from the Nazi medical experiments. In each set of experiments, Cohen discusses how the Jews involved in the experiments suffered, how the research subjects lacked informed consent, and how the experiments were designed to end in death. He is unable to acknowledge that life-saving techniques were developed as a result of Jewish suffering. After reading Cohen's article, it is important to take several thoughts into consideration when determining whether or not using data from Nazi medical experiments is ethical or not: 1) Dr. John Hayward of Victoria University in Vancouver, B.C. says that he does not want to use the research data, but has no choice as

${ }^{30}$ Cohen states, "For Jews, there are times when saving a life is not the ultimate good to be achieved. While it is true that saving a life overrides all other commandments, a Jew is commanded to sacrifice his life rather than transgress the three cardinal sins (idolatry, murder, and sexual immorality)." Babylonian Talmud, Tractate Sanhedrin, (74a), quoted in Cohen, The Ethics of Using Medical Data From Nazi Experiments. 
repeating the research is unethical and impossible; 2) necessary evils exists; 3) without endorsing the National Socialist views, Jewish victimization has to end at some point in order to acknowledge that the Jewish sacrifice provided life-saving techniques; and 4) research is objective. While there are many arguments for using the data and many against using the data, in the long run, history cannot be changed and ignoring life-saving medical techniques and discoveries is unethical in itself.

The first argument presented by Cohen is that people suffered at the hands of the Nazis and despite any positive research outcomes, it is unethical to use results obtained without consent and through torture. Within this argument Cohen also presents the idea that the twisting of language does not justify the medicals experiments either. Other scholars present a utilitarian argument, free from emotion and are thoroughly practical. To honor the victims of these experiments is to use the results to help modern-day patients and to teach physicians that though the experiments were unethical, using the results benefits the greater good. The most relevant issue that can be gleaned from Cohen's article is the description of certain words used by the Nazis. Cohen's linguistic analysis highlights the Nazi penchant for manipulating language and meaning as part of their potent propaganda machine. Not only were the Nazis able to manipulate medical research for their own purposes, they changed everyday language. Cohen calls this a perversion of terminology and claims that it is only one of his many arguments against using the results of the Nazi medical experiments. 
Words such as control group, sample size, and response rate changed from standard research terms to terms that reflect suffering. ${ }^{31}$ While these words have reverted to their original meaning in the years since the end of World War II, there is no question that their veiled definitions had an impact on research ethics. Research results had to be worded carefully, using synonyms for standard terms to avoid offending survivors.

In all basic research there is a control group who receive a placebo, a sample size to control and ensure scientific validity, and a response rate to measure the results of the experiments being conducted. These terms are generally accepted in the scientific and medical world and have the same meaning for everyone. The Nazis used these words to describe research processes as well, but took the meaning of the words and altered them to serve their needs.

This manipulation of language, the removal of neutrality and commonly accepted definitions, is an attack on the integrity of science, but a brilliant plan to keep the true medical experiments a secret as long as possible. This attack consists of removing neutrality and commonly accepted terms of words and replaces the definition with wartime propagandist jargon that furthered and cloaked the Nazi cause. This deception allowed the victims to be kept anonymous and the experiments kept in the dark for a good portion of the war. Cohen suggests that allowing the word 'experiment' continual use violates the memory of the victims of Nazi experiments and that another word should replace what he terms 'beatings' and 'muggings'. During World War II lay people would not have know that a commonly accepted word had a new meaning. This ignorance

\footnotetext{
${ }^{31}$ W.E. Seidelman, Mengele Medicus: Medicine's Nazi Heritage, The Milbank Quarterly, Volume 66, number 2, 1988, quoted in Cohen, The Ethics of Using Medical Data from the Nazi Experiments, 1998.
} 
allowed the Nazis to speak in a kind of code that protected their crimes and weakened scientific integrity.

Cohen's dramatic reaction to the propaganda of language is exactly what the Nazis had in mind when they altered the German language to their advantage. However, when they altered language, they had no idea that they were going to lose the war and be considered criminals in the war's aftermath. Each word they changed gave credence to their experiments and protected them until witnesses to the experiments were unable to hold their tongues. Their language manipulation or code provided a placebo effect for a long time, but not a placebo effect as the term is currently used. The Nazis used the term control group, or those who receive a placebo during a study or experiments, to describe the people in their experiments whose level of pain showed no change throughout the experiment. The only control in this situation was that which the Nazis had over this group, most of whom died before the experiments were completed. ${ }^{32}$ The control group is included in the sample size, which is the entire group of research/experiments subjects, a small and generally manageable number of people. This neutral term, during the Nazi experiments, referred to a truck full of Jews who were most definitely on their way to their death.

The Nazis managed to take readily accepted scientific research terms and hide themselves behind the generally accepted definitions for many years. This use of language as propaganda shows a clear and sophisticated understanding not just of propaganda, but of the trust citizens of the Third Reich had in what they read and heard throughout the war. The Nazis, in their zealousness for eugenics, managed to make

\footnotetext{
32 W.E. Seidelman, Mengele Medicus: Medicine's Nazi Heritage, The Milbank Quarterly, Volume 66, number 2, 1988, quoted in Cohen, The Ethics of Using Medical Data from the Nazi Experiments, 1998.
} 
World War II not just a military war, but also a linguistic war whose manipulations still affect the field of scientific and medical research ethics. Manipulating language in itself is not unethical. It can, however, manipulate neutral words into words that describe horror. It is this change that made Nazi propaganda successful.

Baruch Cohen cites the manipulation of language to enhance his argument against the use of Nazi research and to emphasize his clear opposition to the potential utilitarian value of the Nazi medical experiments. Cohen fails, however, to see the value of science without the emotional pain of his fellow Jews, and this blind faith paints the Nazis even more monstrously in his mind, than in that of other scholars.

Cohen's short comings provide an opportunity for Rael D. Strous and Robert W. Lifton, among others, to make an unemotional argument for the utility of the Nazi experiments and how history, pseudo-science and education prove that not everything about using the experiment results is unethical.

The most supported argument for the use of the Nazi experiment results is that of utility, the greatest good for the greatest number. The utility can be seen clearly in the medico-military experiments the Nazis conducted during World War II. Each of these experiments, while brutal, benefited the German Army during the war and led to further post-war advances in the fields of wound care, altitude sickness, and the re-warming of frozen human bodies--all life saving techniques. This reality is what Cohen and his community are unable to see, and it prevents them from letting go of their anger and indignation.

There were a number of extremely important experiments conducted by the Nazis during the Second World War that improved the lives of not only the German military, 
but militaries around the world who were able to access the experiment results both during and after the war. While the circumstances of the experiments were not ideal, it is possible to put the suffering in context and realize the benefit that experiments in wound treatment, high altitude survival, freezing survival, and sea water survival. Each of these experiments has had a profound impact on contemporary military research and also saved some lives during World War II and after. The utility of these experiments is clear and easily proven. Despite a contentious outcome and the intention to help only the Third Reich, the Nazis were able to extend the lives of many soldiers and prevent them from dying particularly miserable deaths. While their research subjects died under less than ideal circumstances, their deaths led to what are now life saving procedures.

On the other hand, the Freezing Experiments conducted by Dr. Sigmund Rascher, MD provided no viable results. His technique of submerging Jewish prisoners in freezing water and ice was unable to duplicate the temperatures of the North Sea and therefore, the experiment had no control group. Rascher hoped to find a way for pilots to survive ejection when landing in the brutal North Sea, where humans were known to survive only a few hours. His experiments caused a bit of trouble at Dachau and his laboratory was relocated to Auschwitz where he worked with Dr. Josef Mengele. The Freezing Experiments were unethical because they violated the ethics of rights and care. This experiment did, however, bring about re-warming techniques that physicians use today. Rascher determined that heat must be introduced both internally and externally in order for a hypothermia victim to survive. Rascher's re-warming technique, with modern modifications, is the norm for the treatment of hypothermia victims today. 
In 1942, Rascher was working on High Altitude Experiments. His goal was to determine the best way to rescue pilots who must abandon their aircraft at high altitudes without oxygen equipment. While Rascher did not find a solution to abandoning an aircraft without oxygen equipment, he did discover that high altitude sickness is caused by the formation of air bubbles in blood vessels in the brain. When they rupture, the subject experiences an aneurysm and dies. Rascher used a decompression chamber to simulate pilots who abandoned their aircraft at high altitude and then dissected the brains of the victims to prove his theory. Dissecting the brain of a living subject is unethical, but Rascher's discovery of the air bubbles in the brain's blood vessels changed how physicians and scientists analyze and treat high altitude sickness. ${ }^{33}$ Despite the unethical research practices, Rascher's experiments benefited all pilots.

The Sea Water Experiments were equally as inconclusive as Rascher's Freezing Experiments. Conducted by Dr. Hans Eppinger on ninety Gypsies at Dachau, Eppinger succeeded only in proving that a fluid supply consisting only of sea water causes severe physical issues, extreme dehydration, and death within a week to a week and a half. ${ }^{34}$ Eppinger killed himself in 1946, only a month before he was to testify at the Nuremberg Trials. His experiment, while being a practical idea, amounted to nothing and was seen as the torture of Gypsies. There is a veiled sense of utility here, utility in that Dr. Eppinger's experiments meant to benefit pilots and other soldiers who found themselves

\footnotetext{
33 J.S. Hayward, Physiological Responses \& Survival Time Predictions for Humans in Ice Water, Aviation Space \& Environmental Medicine, March, 1984, 55(3): 206-12; J. Boozer, The Political, Moral \& Professional Implications of the Justifications by German Doctors for Lethal Medical Actions, 1938-1945; and L.J. Hoenig, MD, The Nazi Medical Crimes, Medical Times, July, 1987, pp 93-104, all quoted in Cohen, The Ethics of Using Medical Data From Nazi Experiments, 1998.

${ }^{34}$ H.M. Spiro, MD, Eppinger of Vienna: Scientist \& Villain?, Journal of Clinical Gastroenterology 6:493497, 1984, quoted in Cohen, The Ethics of Using Medical Data from Nazi Experiments, 1998.
} 
waiting for rescue at sea. The only scientific outcome was the widely known fact that sea water is not potable.

Many of the experiments conducted during World War II were, in fact, conducted merely out of curiosity and not for any greater purpose. This does not contradict the positive discoveries that came out of the experiments and should not impact whether or not the results are used or cited in modern-day research. Research and experiments, even those conducted under duress still have the potential to provide helpful results. While the brutality of the experiments violates the subject's rights, justice, and care, the utility supercedes the violations. As in the hypothermia research, physicians now have a more efficient technique to save those with dangerously low body temperatures. The Nazis discovered that the techniques used before and during World War II were futile and that the key to bringing a body back from hypothermia was not only to warm the body from the outside, but to introduce warm fluids intravenously. This method continues to be used in hypothermia cases around the world. The fallacy in the Cohen article is that he is unable to separate his indignation from the utility of the beneficial research. This utility honors the suffering of the Jewish research subjects and facilitates a new level of care for today's patients.

Rael Strous, Hanfried Helmchen and Gregory Stock present interesting counter arguments to that of Baruch Cohen. While they are able to understand the utility in the Nazi experiments, they are also able to empathize with Cohen and the Jewish community that he represents. The main difference between Cohen and his contemporaries is that Cohen is not a physician or a medical researcher. Strous, Helmchen and Stock are 
seasoned medical researchers and writers, whose perspective is refreshing and without the fervor of religion that dominates much of Cohen's writing.

Rael Strous, writing for the Annals of General Psychiatry looks at medical ethics as culturally and historically contingent, but reminds medical students that there is still a clearly defined responsibility to conduct ethical research at all times and to learn from the mistakes made by Nazi physicians. ${ }^{35}$ Strous also acknowledges that the field of psychiatry was especially guilty in supporting both Zwangssterlisation and the EP/OT4. Helmchen adds to Strous' argument and states that certain ethical elements transcend time and some elements evolve over time, but that "...the basis for ethical behavior should remain constant, irrespective of time and place."36 What both Helmchen and Strous agree on is that medical ethics can be contingent upon resources and culture, but that the contingency does not supercede ethical considerations of the Nazis experiments. Both scholars believe that the Nazi experiments were beneficial to modern medicine and medical research, but that the processes themselves were unethical and based on the pseudo-science of eugenics.

While it is clear that research should be ethical at all costs, Gregory Stock makes a point that Strous and his contemporaries fail to address. Stock ironically points out that physicians have a responsibility to the rest of the world to improve mankind. In an article for DNA Cell Biology, Stock points out that the very beginnings of the idea of racial purification grew not out of a desire to cleanse the world of Lebensunwertestleben, but a

\footnotetext{
35 Strous, G., Annals of General Psychiatry, 2007, 6:8.

${ }^{36}$ Helmchen, H., Forthcoming ethical issues in biological psychiatry, World J Biol Psychiatry, 2005, 6(Suppl 2): 56-64, quote in Strous, Annals of General Psychiatry, 2007, 6:8.
} 
desire to improve mankind. ${ }^{37}$ Stock's idea is the essence of utility and demonstrates his clear understanding that medicine itself, including human experimentation, exists only to provide the best medicine, the greatest good, for everyone in the world, the greatest number. Stock completes his argument by explaining that the improvement of mankind continues in modern medicine "...through molecular biology and genetic engineering." Rael Strous acknowledges this argument, but provides the caveat that within the dialogue surrounding the improvement of mankind, both scientists and physicians must remember that this utilitarian desire to improve the human race cannot come at the expense of individual patients. ${ }^{38}$

The problem with the Nazi medical and military experiments is very simple to describe, but their use and ethical value are a dialogue that will continue. The utilitarian argument is clear, unemotional, and the strongest argument for using the experimental results in modern medicine and modern medical research. In each of their arguments, Baruch Cohen, Rael Strous, and Gregory Stock state that the research subjects, or Cohen's victims, must be honored in some way and that current and future physicians must learn from the Nazi's missteps. The problem with the Nazi experiments is not whether or not they were ethical experiments; it is that the research subjects were subjected to experiments against their will, without compensation, and not just with the intent to improve life for German soldiers, but to torture and kill the research subjects. The Nazis made great advancements in a few areas of medico-military research, but their methods were flawed, however. However, unethical methods do not discount the

\footnotetext{
${ }^{37}$ Stock, G., From regenerative medicine to human design: what are we really afraid of? DNAA Cell Biology 2003, 22:679-83, quote in Strous, Annals of General Psychiatry 2007, 6:8.

38 Rael Strous' article speaks more to psychiatry during the Nazi era than anything else, but he concludes that medical professionals as a whole must put their patients first and research second.
} 
positive value of the discoveries made. The methods are unethical, the results are utilitarian and therefore ethical. Physicians are taught to remember the unethical methods and the mistreatment of the research subjects by the Nazis, but are also aware that some of the experiments provided useable and enduring results that save lives. 


\section{CHAPTER 5}

\section{i. DEATH AND DELIVERANCE:}

A review of recent scholarly secondary literature on Operation T-4

In 1994, Michael Burleigh took on the emotional and rather burdensome task of evaluating the Nazi euthanasia program, a program that dominated, albeit it secretly, the lives of many Germans, their family members, and the murderers who carried out the euthanasia itself. While a daunting task, in Death and Deliverance: Euthanasia in Germany 1900-1945, Burleigh was able to take these horrors and turn them into a wellwritten, unbiased and informative history. David Ceserani of The Guardian wrote that "History writing is rarely this moving, or so admirably, effectively moralistic." "This is a terrible book. Everyone ought to read it. It is difficult to believe that this account could be improved upon" agrees Anthony Storr of The Times. This is one of the most "penetrating[ly]" (Niall Ferguson, The Sunday Telegraph) "harrowing” (Jonathan Meades, Mail on Sunday) books that has ever been written on the subject of euthanasia in our time. Burleigh lends brutal honesty to this story of unnecessary and remorseless murder carried out by the Nazis.

In his book, Burleigh brings together the available scholarly research into a cohesive collection that highlights his expertise. In comparing his ideas to those of Nicholas Stargardt and Mary Fulbrook, Burleigh makes researchers aware of conflicting opinions and does not allow his ideas to overshadow those of his peers. The field of medical ethics is complicated and multi-faceted. Burleigh is able to bring together all the facets in a way that helps researchers form their own ideas with the support of the most knowledgeable scholars in this area. 
There are so many different issues at hand in the discussion of euthanasia and in the field of medical and bioethics. It is complicated, often historically and situationally contingent, but according to Burleigh's tone, never justified. He gives a fair literary trial to the Nazis and their accomplices and properly, solemnly, and gracefully eulogizes those who were lost during the euthanasia program.

\begin{abstract}
Euthanasia in early 20th-century Germany has often been linked to other bioethical issues, such as abortion, sterilization, concentration-camp experiments, and to the events of the Holocaust. These linkages often influence the assessment of the German experience and its relevance to medical practice in other countries. Some have seen the concentration of evils in Germany as unthinkable elsewhere, whereas others have used some combination of these historical events in advancing slippery-slope arguments. The first group regularly ignores the advocacy of euthanasia in pre-Nazi Germany; the second group often leaves important issues related to euthanasia unexplored. In Death and Deliverance, Burleigh rarely departs from his focus on euthanasia and provides good coverage of pre-Nazi developments (Yeide).
\end{abstract}

Yeide writes that Burleigh is able to make the leap from euthanasia to other bioethical issues, making him qualified to analyze the Nazi EP/OT4 with a perspective that bears in mind the "slippery slope" theory, in addition to exploring many issues surrounding euthanasia including propaganda, films, and the eugenics movement. Burleigh is a literary and historical jack of all trades whose perspective on the EP/OT4 gives insight that others have yet to achieve.

While Dr. Yeide finds Burleigh to be "crude" and macabre, he finds the book to have few drawbacks and it paints a clear picture of what went on during Aktion T-4, the Euthanaise Programme, and the trials that commenced at the end of the war. While Burleigh clearly paints the Nazis as murderous brutes and tends to err on the side of accusation, his facts are accurate, his writing clear, and the story both engaging and horrifying at the same time. This is an appalling part of history, not only on the part of the Nazi regime, and Burleigh leads us through the muck eloquently, stepping delicately 
through the faces of the victims and treading very hard on the terrifying masks of their murderers. Clearly Burleigh's account of the euthanasia program has a great influence on the people who both read and review his book. It is difficult to come away from Death and Deliverance: Euthanasia in Germany 1900-1945 without having experienced full body tremors, nightmares, and extremes in emotional responses hitherto inexperienced. Michael Burleigh more than succeeds in reporting history, in all of its terribleness, and still leaves the reader with the hope that such occurrences shall never again come to pass. While Burleigh's book focuses wholly on euthanasia, Mary Fulbrook's A History of Germany 1918-2008: The Divided Nation merely glosses over the euthanasia program as a part of the Holocaust and a precursor to the industrialized extermination of Jews that continued until the end of the war. Fulbrook does not lend T-4/euthanasia the time or credence it deservers. Similarly, in Fulbrook's German History since 1800, the essay by Nicholas Stargardt mentions the T-4 Program and euthanasia, but also focuses less on these mentally ill victims and more on the Jews, who were also brutally massacred during World War II. Euthanasia and the killing of Jews, Gypsies, etc. were not specific to the "Final Solution" and actually began, as far as euthanasia is concerned, during World War I and the latter, in the late 1930s after Hitler came to power. While Fulbrook does not spend a great deal of time on euthanasia, it is clear from her own writing and her selection of Nicholas Stargardt's article, that it was an important part of their histories and historiographies of World War II and the ensuing Holocaust.

Mary Fulbrook gives an excellent historical account of the beginning of the T-4 Program in her A History of Germany 1918-2008: The Divided Nation, but really fails to expand upon the true depth of the destruction that these Nazi killers wreaked on German 
society. Only briefly does Fulbrook discuss the "rationale" behind the euthanasia program, where Burleigh devotes several in depth chapters to the doctors, politicians, and propagandists who helped Adolf Hitler develop the program. Fulbrook also somewhat wrongly includes Jehovah's Witness, homosexuals, and Gypsies into the victims of the T4 Program. It was not until the end of the war that the T-4 commanders added these innocents to their lists of Lebensunwertesleben. Fulbrook devotes most of her related chapter to the extermination (through means similar to those imposed by the T-4 Program) of the Jews through gassing, shootings, starvation, and inevitable cremation. Burleigh, on the other hand, spends hundreds of pages on the plight of the mentally ill. Fulbrook and Burleigh do, however, agree that the killings began to increase in rate as the campaign on the Eastern Front came to a grinding halt in the winter of 1942. Doctors in the T-4 Program began to increase their "selections" of those who were to be gassed during this time because they believed that spending less money on Lebensunwertesleben would provide more for the soldiers fighting for the Reich on the Eastern Front. Despite this "well-reasoned" argument, the efforts of T-4 doctors did nothing to alleviate the mass casualties and poor decisions of those fighting and directing the battle on the Eastern Front. These doctors increased their killing so as to provide beds for the young and fit soldiers coming back from the Eastern Front to recover:

\footnotetext{
"...It was time to "draw the final consequences in terms of eradication, with respect to the medical care of lives unworthy of life.' Two groups would be affected: 'the totally idiotic, thoroughly asocial, absolutely dependent, chronic cases' and 'criminally inclined, anti-social elements' in protective custody who were 'burdening and filling up' the asylums. Discussions were taking place as to whether to keep these people 'under the most primitive conditions' or whether to 'eradicate them'....He [Dr. Pfannmüller] found it incomprehensible that young, fit men were dying at the Front while 'living corpses' were being maintained in the asylums" (Burleigh 228) .
} 
Burleigh describes the essence of the EP/OT4, to eliminate anyone who would be a reproductive danger to the Reich. The decision of who to eliminate was summary and cruel, though the doctors believed that disposing of Lebensunwertesleben would benefit the young men fighting for the Reich. What both Burleigh and Fulbrook come to realize is that no matter what their motivation, the euthanasia program continued as long as it could up and until D-Day in June 1944 and beyond and to the point where residents of the towns surrounding these killing centers became curious.

In Mary Fulbrook's edited collection of essays, Germany History since 1800, Nicholas Stargardt takes on the humbling task of discussing the Holocaust and the death camps that rose out of hell during this period. Stargardt glosses over the euthanasia program, mentioning only that euthanasia was a precursor to the industrialized mass killings of Jews and that the modus operandi for these killing were "mobile gas vans...left over from the so-called 'euthanasia' action against asylum patients" (Stargardt in Fulbrook, 339). However, Stargardt, like Burleigh (though not as extensively), goes into a bit of detail regarding the pre-war sterilizations and killings that were carried out by these same doctors. Stargardt makes the very important link between these pre-war killings and the eventual (near) destruction of the Jewish population in Europe. Burleigh spends quite some time making this connection, but not nearly in the concise way that Nicholas Stargardt does. Stargardt goes on to mention that nearly 4000 mental patients were also brutally murdered in Poland almost immediately after the start of the war in 1939. Burleigh fails to go into detail about the similar murders of the mentally ill, Jews notwithstanding, that occurred outside the Reich, though he does allude to them. Stargardt also mentions that once the order to put an eventual end to T-4 was given, 
though never really obeyed, that "many of its personnel were transferred to the Einsatzgruppen and to set up the death camps" (Stargardt in Fulbrook, 349). Burleigh also mentions this transition, which happened with some personnel before T-4 was deconstructed as they were jostled between different asylums within Germany, temporarily to Russia and then back to Germany, with "mercy killings" being carried out all the while:

\begin{abstract}
"Finally we come back to Pauline K, who, worked successfully in Grafeneck, Hadamar, Bernburg and Kaufbeuren-Irsee. In 1944, Faltlhauser asked the Ministry of the Interior for personnel who would be able to carry out 'euthanasia.' The staff at T4, ever-present in the shadows, sent him Pauline K., who had actually been to Kaufbeuren before....Faltlhauser told her which patients to kill, asking whether she could do the job alone. She said that she could, having done so at Hadamar....Although Pauline K. never ventured a word about what she was doing in the asylum, the storms seem to have triggered memories of her winter in Russia. Perhaps this reminder of human vulnerability to element forces stirred some vestiges of guilt. She said she regretted having given German soldiers lethal injections in military hospitals. Asked why she had done this, she said that it had paid well. Apparently the victims were not badly wounded, but mad" (Burleigh 243).
\end{abstract}

As Burleigh shows us with Pauline K., not only were personnel shipped around Germany and to the Eastern Front, but they even killed the soldiers who were fighting for the good of the Reich. These people were ending the lives of those considered to be Lebensunwertesleben, playing God, killing indiscriminately, for the good of the Reich, in the name of Adolf Hitler, but also killing the very people who had fought "the good fight.” Fulbrook, Burleigh and Stargardt seem to agree on a few simple facts: (1) that these personnel were vicious, vile, pathological monsters; (2) that T-4 killed mentally ill patients in asylums; and (3) that T-4 eventually led to the incorporated, industrialized and widespread killing of Jews (and others) during the Holocaust, the Final Solution.

What all of these authors tend to leave out is the bioethical argument for and against "mercy killings". Burleigh clearly is against any and all forms of "mercy 
killings" or euthanasia: "Burleigh's distaste for the euthanizers is often reflected in his crude descriptions...” laments Dr. Harry Yeide Jr. in The New England Journal of Medicine, but goes on to say that “...One can be equally appalled by this history and by the frequent absence of meaningful punishment for abuses without resorting to such measures. Burleigh also is more contemptuous than I am of compromises that many made to save at least some lives." He paints every last participant in the program as a dogmatic, calculated, unfeeling murderer, with no chance of redemption. Fulbrook and Stargardt do not delve deeply enough into T-4 and "mercy killings" to really have a solid opinion one way or the other. While the reader comes away from these three works with quite a bit of knowledge, historical, mathematical, and social, there is never a clear line that delineates the argument between right and wrong, ethical and unethical. This line, as Yeide mentions, also involves issues such as abortion and the concentration camp experiments conducted by Dr. Josef Mengele and his cronies.

Michael Burleigh, Mary Fulbrook and Nicholas Stargardt are all clear in their base assessment of euthanasia and the T-4 Program. They all clearly abhor the practice, but Fulbrook and Stargardt seem to intentionally give T-4 very little credence and focus back on the mass extermination of Europe's Jews, forgetting entirely that another group of people, some "Aryan" in fact, were brutally murdered as well.

Michael Burleigh is biased and angry and even a bit vindictive. But he is nonetheless able to write a well-rounded, horrific, terrifying, and impactful book that will most likely stay with readers for the rest of their lives. His organic use of statistics and unadorned descriptions give the reader a chilling sense of what life was like at institutions 
like Hadamar. The reader yearns to take these mentally ill patients and protect them and to give them a voice. 


\section{CHAPTER 6}

The Nazis committed heinous crimes during World War II and though many were indicted, sentenced, and hanged, that does not affect how their actions penetrate modern history, ethics or medicine. Utility now has the possibility to be used to justify unethical actions that are practical in times of war; research ethics are fuzzy because human experimentation is beneficial to the elimination of severe diseases and medicine has to have the opportunity to cite unethical practices as both a warning to new physicians and to make use of experiment results that are beneficial to modern medicine. Though the Nazis were criminals, their criminal acts led to some positive developments.

The Nazis were able to correctly justify Zwangssterilisation by making the point that those suffering from Erbkrankheiten would produce equally or more severely Erbkrank children who would be a burden on society. The Nazis argued that sterilizing these citizens, albeit without their knowledge or against their will, served the best purposes of the community they lived in and eliminated further generations of Erbkranke. The sterilizations themselves were cruel and some citizens died, but to strengthen the Reich, to eliminate unnecessary care costs, the Nazis felt that sterilization was the best solution to people who were a drain on society.

Zwangssterilisation, however, turned into the EP/OT4, which used a linguistic manipulation justifying murder of those too weak or idiotic to fight for their lives. Euthanasia is defined as mercy killings, reserved for those suffering from terminal and painful illnesses. The Nazis managed to pervert what is perceived as a merciful action and murdered people under the guise of falsified medical records. This change to the language mandated that physicians redefine the term to bring it back to mercy killing and 
not a cover for murder so as to provide those suffering a terminal illness with a way to end their lives with dignity. Those citizens who died during the EP/OT4, died without dignity and at the hands of physicians who broke their Hippocratic Oath to do their patients no harm or intentionally cause their death. Euthanasia continues to be a difficult topic, made more volatile because of the actions of the Nazis.

The Nazis also managed to change how medical research is read, cited, and conducted. General research terms lost their meaning during World War II Nazi medical experiments. Neutral terms that described neutral processes became terms to describe torture, level of pain, and reactions to pain. While lay people continued to see such terms as neutral, the Nazis perverted them to a point where citing the research is difficult and presents never before seen ethical questions. Though most of the Nazi experiments were unethical and conducted out of uneducated curiosity, some experiments produced results that positively impacted modern medicine. The citation of these useful experiments is controversial due to the suffering and death of the experiment subjects. However, the use and citation of Nazi medical research can honor the victims who unknowingly gave their lives for the advancement of modern medicine. While their lives ended terribly, their deaths continue to give others life.

There is no doubt that the Nazis committed terrible crimes at Hadamar and countless other places like it. Their actions changed the face of medical ethics for finding a way to justify Zwangssterilisation as the greatest good for the community they served. The Nazis also made important advancements in modern medicine. This recognition, however, does not absolve the Nazis of their crimes, nor does it justify all the murders 
they committed — what it does do is acknowledge that the Nazis were intelligent people perverted by a megalomaniac and selfish commitment to victory at all costs. 
WORKS CITED

Aly, Götz, Peter Chroust and Christian Pross. Cleansing the Fatherland Nazi Medicine and Racial Hygiene. Baltimore and London: The Johns Hopkins University Press, 1994.

Bard, Mitchell G., ed. The Development of the Gas-Van in the Murdering of the Jews. The Jewish Virtual Library A Division of The American-Israeli Cooperative Enterprise: 1998.

Bard, Mitchell G., ed. The T-4 Euthanasia Program. The Jewish Virtual Library A Division of The American-Israeli Cooperative Enterprise: 1998.

Boozer, J. The Political, Moral \& Professional Implications of the "Justifications" by German Doctors for Lethal Medical Actions, 1938-1945. N.p.

Buck vs. Bell, 274 U.S. 200 (1927)

Burleigh, Michael. Death and Deliverance: Euthanasia in Germany 1900-1945. London: Cambridge University Press, 1994.

Cohen, Baruch. The Ethics Of Using Medical Data From Nazi Experiments. N.p.: The Jewish Virtual Library A Division of The American-Israeli Cooperative Enterprise: 1998. 
Franke, Klaus. "Reine Rasse: Gendiagnostik, Klonen, Sterbehilfe: Wenn Wissenschaftler den Fortschritt feiern, lösen sie auch heftige Abwehrreflexe aus. Denn die Erinnerung an die Euthanasie-Mordaktionen der Nazis bleibt wach“. Spiegel Special: Das Magazin zum Thema Die Gegenwart der Vergangenheit, Die Spiegel-Serie Über den Langen Schatten des Dritten Reichs. Number 1, 2001 : pgs. $132-38$.

Friedlander, Henry. The Origins of Nazi Genocide: From Euthanasia to The Final Solution. Chapel Hill, North Carolina: The University of North Carolina Press, 1995.

Fulbrook, Mary. A History of Germany 1918-2008: The Divided Nation 3rd Edition. Malden, MA: Wiley-Blackwell, 2009.

Fulbrook, Mary. German History since 1800. New York, New York: Hodder Headline Group, 1997.

Green, Leslie C. Rev. Of The Hadamar Trial by Earl W. Kintner. West Sussex, United Kingdom: The Modern Law Review, Volume 13, Number 3, 1950 Jul: pgs. 408409.

Helmchen, H. "Forthcoming ethical issues in biological psychiatry". World J Psychiatry. 2005, 6 (Suppl 2): 56-64. 
Hoenig, L.J. “The Nazi Medical Crimes“. Medical Times. 1987 Jul: pp 93-104.

Lifton, Robert J. The Nazi Doctors: Medical Killing and the Psychology of Genocide. New York, New York: Basic Books, Inc., 1986.

Meusch, Matthias. "Hadamar: a German psychiatric treatment center in WWII". Biomolecular Engineering. Volume 17, 2001: pgs. 65-69.

Power, Samantha. "A Problem from Hell" America and the Age of Genocide. New York, New York: Basic Books, 2002.

Proctor, Robert. Racial Hygiene: Medicine Under the Nazis. London: Harvard University Press, 1988.

Seidelman, William E. “Mengele's Medicus: Medicine's Nazi Heritage“. The Milbank Quarterly, Volume 66, number 2, 1988.

Stargardt, Nicholas. The Holocaust. New York, New York: Hodder Headline Group, 1997.

Stock, Gregory. "From regenerative medicine to human design: what are we really afraid of?“ DNA Cell Biology, 2003, 22: 679-83. 
Strous, Rael D. "Images in Psychiatry: Nazi Euthanasia of the Mentally Ill at Hadamar". American Journal of Psychiatry. Volume 163, Number 1, 2006 Jan.

Strous, Rael D. "Nazi Euthanasia of the Mentally Ill at Hadamar". American Journal of Psychiatry. Volume 163, Number 1, 2006 Jan: pg. 27.

Strous, Rael D. "Psychiatry during the Nazi era: ethical lessons for the modern professional“. Annals of General Psychiatry. Volume 8, Issue 8, 2007 Feb 27.

Strous, Rael D. "Psychiatric Genocide: Reflections and Responsibilities". The Author by Oxford University Press on behalf of the Maryland Psychiatric Research Center, 2010.

Von Galen, Clemens August Graf. "Predigt von Galens zur Ermordung Behinderter". Informationen zur politischen Bildung. Volume 243, 2000: pg. 21.

Yeide Jr., Harry. Rev. of Death and Deliverance: Euthanasia in Germany 1900-1945. The New England Journal of Medicine. Volume 332/1772, Number 25, 1995 June 22. 


\section{BIBLIOGRAPHY}

Alexander, Leo. "Medical Science Under Dictatorship". The New England Journal of Medicine, Volume 241, Number 2, 1949 Jul 14: pgs. 39-47.

Bard, Mitchell G., ed. Documents Regarding Medical Experiments. The Jewish Virtual Library A Division of The American-Israeli Cooperative Enterprise: 1998.

Bard, Mitchell G., ed. Nazi Extermination of People with Mental Disabilities. The Jewish Virtual Library A Division of The American-Israeli Cooperative Enterprise: 1998.

Bard, Mitchell G., ed. Sterilization of Jewish Workers. The Jewish Virtual Library A Division of The American-Israeli Cooperative Enterprise: 1998.

Bard, Mitchell G., ed. The Development of the Gas-Van in the Murdering of the Jews. The Jewish Virtual Library A Division of The American-Israeli Cooperative Enterprise: 1998.

Bard, Mitchell G., ed. The T-4 Euthanasia Program. The Jewish Virtual Library A Division of The American-Israeli Cooperative Enterprise: 1998. 
Baron, J.H. "Compulsory sterilization of defective people was legal in several countries besides Germany“. British Medical Journal, Volume 314, 8 February 1997: pg. 440.

Bastian, Till. Furchtbare Ärzte: Medizinische Verbrechen im Dritten Reich. München: C.H. Beck’sche Verlagsbuchhandlung (Oscar Beck), 1995.

Bauer, Kurt. Nationalsozialismus Ursprünge, Anfang, Aufstieg und Fall. Wien, Köln, Weimar: Böhlau Verlag, 2008.

Baum, Rachel Nahmacher. Ethics in the Face of Auschwitz: The Emotional and Pedagogical Responsibility of Holocaust Remembrance. Milwaukee: University of Wisconsin Press, 1997.

Beer, Mathias. "Die Entwicklung der Gaswagen beim Mord an den Juden“. Vierteljahreshefte für Zeitgeschichte. Volume 37, 3: pp. 403-417.

Benedict, Susan. "Killing While Caring: The Nurses of Hadamar". Issues in Mental Health Nursing, College of Nursing Medical University of South Carolina, Ralph H. Johnson A Medical Center, Charleston, South Carolina: 2003. 
Berg, Manfred and Geoffrey Cocks, eds. Medicine and Modernity: Public Health and Medical Care in Nineteenth and Twentieth-Century Germany. Washington, D.C. and Cambridge, England: German Historical Institute, 1997.

Blacker, C.P. "Eugenic"Experiments Conducted By The Nazis On Human Subjects. London, England: Eugenics Review, Vol. XLIV, No. 1, 1952.

Boozer, J. The Political, Moral \& Professional Implications of the "Justifications" by German Doctors for Lethal Medical Actions, 1938-1945. N.p.

Borowy, Iris and Wolf D. Gruner, eds. Facing Illness in Troubled Times: Health in Europe in the Interwar Years 1918-1939. Frankfurt am Main: Peter Lang Europäischer Verlag der Wissenschaften, 2005.

Boyd, Kenneth. "What can medical ethics learn from history?" Journal of medical ethics. Volume 21, Edinburgh, Scotland: pp. 197-198, 1995.

Bundesärztekammer (Arbeitsgemeinschaft der westdeutschen Ärztekammern). Gesundheits-und sozialpolitische Vorstellungen der deutschen Ärzteschaft. Köln: Deutscher Ärzte-Verlag, 1986.

Buckvs. Bell, 274 U.S. 200 (1927) 
Burleigh, Michael. Death and Deliverance: Euthanasia in Germany 1900-1945. London: Cambridge University Press, 1994.

California Medical Association Committee for Continuing Study of Evolving Trends in Society Affecting Life. "Euthanasia-An Overview for Our Time". The Western Journal of Medicine, Volume 118 (3), N.p.: March 1973.

Caplan, Arthur. When Medicine Went Mad: Bioethics and the Holocaust. New Jersey: Humana Press, 1992.

Cohen, Baruch. The Ethics Of Using Medical Data From Nazi Experiments. N.p.: The Jewish Virtual Library A Division of The American-Israeli Cooperative Enterprise: 1998.

Crace. John. "Michael Burleigh: The reluctant guru“. The Guardian, 11 March 2008.

Coller, Barry S. "The physician-scientest, the state and the oath: thoughts for our times". The Journal of Clinical Investigation. Volume 116, Number 10, October 2006: pgs. 2567-70.

Derr, Patrick G. "Hadamar, Hippocrates, and the future of medicine: reflections on euthanasia and the history of German medicine“. Issues in Law \& Medicine. 4.n4, Spring 1989: pgs. 487-495. 
Dwork, Deborah and Robert Jan van Pelt. Holocaust A History. New York, New York: W.W. Norton \& Company: 2003.

Drobniewski, Francis. "Why did Nazi doctors break their 'Hippocratic' oaths?" Journal of the Royal Society of Medicine. Volume 86, September 1993: pgs. 541-543.

Fleischman, Alan R. "Regulating Research With Human Subjects-Is the System Broken?" Transactions of the American Clinical and Climatological Association. Volume 116, 2005: pgs. 91-102.

Franke, Klaus. "Reine Rasse: Gendiagnostik, Klonen, Sterbehilfe: Wenn Wissenschaftler den Fortschritt feiern, lösen sie auch heftige Abwehrreflexe aus. Denn die Erinnerung an die Euthanasie-Mordaktionen der Nazis bleibt wach“. $\underline{\text { Spiegel }}$ Special: Das Magazin zum Thema Die Gegenwart der Vergangenheit, Die Spiegel-Serie Über den Langen Schatten des Dritten Reichs. Number 1, 2001: pgs. 132-38.

Frei, Norbert. Medizin und Gesundheitspolitik in der NS-Zeit. München: Institut für Zeitgeschichte, R. Oldenbourg Verlag, 1991.

Friedlander, Henry. The Origins of Nazi Genocide: From Euthanasia to The Final Solution. Chapel Hill, North Carolina: The University of North Carolina Press, 1995. 
Frewer, Andreas. "Human rights from the Nuremberg Doctors Trial to the Geneva Declaration. Persons and institutions in medical ethics and history“. Med Health Care and Philos. Volume 13, 2010: 259-68.

Frewer, Andreas and Günther Siedbürger, eds. Medizin und Zwangsarbeit im Nationalsozialismus Einführung und Quellen für Unterricht und Selbststudium. Frankfurt am Main: Mabuse-Verlag GmbH, 2006.

Fulbrook, Mary. A History of Germany 1918-2008: The Divided Nation 3rd Edition. Malden, MA: Wiley-Blackwell, 2009.

Fulbrook, Mary. German History since 1800. New York, New York: Hodder Headline Group, 1997.

Gaida, Ulrike. Zwischen Pflegen und Töten: Krankenschwestern im Nationalsozialismus Einführung und Quellen für Unterricht und Selbststudium. Frankfurt am Main: Mabuse-Verlag GmbH, 2006.

Gillon, Raanan. "On sterilising severely mentally handicapped people“. medical ethics. Volume 13, 1987: pgs. 59-61. 
Gottweis, Herbert. "Stem Cell Policies in the United States and in Germany: Between Bioethics and Regulation“. Policy Studies Journal. Volume 30, Number 4, 2002: pgs. 444-469.

Gottweis, Herbert and Wolfgang Hable, Barbara Prainsack and Doris Wydra. Verwaltete

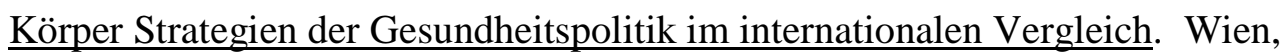
Köln and Weimar: Böhlau Verlag GmbH, 2004.

Green, Leslie C. Rev. Of The Hadamar Trial by Earl W. Kintner. West Sussex, United Kingdom: The Modern Law Review, Volume 13, Number 3, 1950 Jul: pgs. 408409.

Grobin, W. "Medical Assessment of Late Effects of National Socialist Persecution". Canadian Medical Assessment Journal. Volume 92, 24 Apr 1965: pgs. 911-17.

Hannah, Margaret. "Use of Nazi material during medical training left an uncomfortable feeling“. Letter. British Medical Journal 8 February 1997: 440.

Hayward, J.S. "Physiological Responses \& Survival Time Prediction for Humans in Ice Water“. Aviation Space \& Environmental Medicine, Volume 55, Number 3, 1984 March: pgs. 206-12. 
Hirschfeld, Gerhard and Tobias Jersak, eds. Karrieren im Nationalsozialismus Funktionseliten Zwischen Mitwirkung und Distanz. Frankfurt/Main: Campus Verling GmbH, 2004.

Hoenig, L.J. “The Nazi Medical Crimes“. Medical Times. 1987 Jul: pp 93-104.

Horn, Sonia and Peter Malina, eds. Sozialgeschichte der Medizin im Nationalsozialismus-Wege der Aufarbeitung. Wien: Verlag der Österreichischen Ärztekammer, 2001.

Karenberg, Axel. "Neurosciences and the Third Reich". Journal of the History of the Neurosciences. Volume 15, 2006: 168-72.

Kater, Michael H. Doctors Under Hitler. Chapel Hill, North Carolina: The University of North Carolina Press, 1989.

Kazimierz, Leszczynski. “'Guinea pigs’ of Ravensbruck“. Experimental Operations On Prisoners of Ravensbruck Concentration Camp, Studies and Monographies. 1960, December.

Kershaw, Ian. Die Nazis Eine Warnung der Geschichte. München: Wilhelm Heyne Verlag GmbH AG, 1997. 
Kevorkian, Jack. “A Brief History of Experimentation On Condemned and Executed Humans“. Journal of the National Medical Association. Volume 77, Number 3, 1985: pgs. 215-26.

Klee, Ernst. Was sie taten—was sie wurden: Ärzte, Juristen und andere Beteiligte am Kranken oder Judenmord. Frankfurt am Main: Fischer Taschenbuch Verlag $\mathrm{GmbH}, 1986$.

Koessler, Maximilian. "Euthanasia at Hadamar Sanatorium and International Law". The Journal of Criminal Law, Criminology and Police Science. Volume 43, Number 6, 1953 Mar-Apr: pgs. 735-55.

Kottow, M.H. "Should medical ethics justify violence?" Journal of Medical Ethics. Volume 32, 2006: pgs. 464-67.

Kudlien, Fridolf. Ärzte im Nationalsozialismus. Köln: Kiepenheuer \& Witsch Verlag, 1985.

Lifton, Robert J. The Nazi Doctors: Medical Killing and the Psychology of Genocide. New York, New York: Basic Books, Inc., 1986. 
Mellanby, Kenneth. "Medical Experiments On Human Beings In Concentration Camps in Nazi Germany“. British Medical Journal. Volume 148, 1947 Jan 25: pgs. 148150.

Meusch, Matthias. "Hadamar: a German psychiatric treatment center in WWII". Biomolecular Engineering. Volume 17, 2001: pgs. 65-69.

Michalczyk, John J ed. Medicine, Ethics and the Third Reich. Kansas City, Missouri: Sheed and Ward, 1994.

Mitscherlich, Alexander and Fred Mielke eds. Medizin ohne Menschlichkeit: Dokumente des Nürnberger Ärzteprozesses. Frankfurt am Main and Hamburg: Fischer Bücherei KG, 1949.

Mosse, George L. Nazi Culture: Intellectual, Cultural and Social Life in the Third Reich. Madison, Wisconsin: The University of Wisconsin Press, 1966.

Müller, Christine-Ruth and Hans-Ludwig Siemen. Warum sie sterben mussten: Leidensweg und Vernichtung von Behinderten aus den Neuendettelsauer Pflegeanstalten im "Dritten Reich“. Nürnberg, Germany: Verein für bayerische Kirchengeschichte in Kommission bei Verlag Degener \& Co., 1991. 
Nitschke, Asmus. Die "Erbpolizei" im Nationalsozialismus zur Alltagsgeschichte der Gesundheitsämter im Dritten Reich. Opladen, Wiesbaden: Westdeutscher Verlag GmbH, 1999.

O’Mathuna, Donal. "Human dignity in the Nazi era: implications for contemporary bioethics“. BioMed Central Medical Ethics. Volume 7, Issue 2, 200614 Mar.

O'Reilly, Michael. 'Nazi medicine: 'The perversion of the noblest profession'. Canadian Medical Association Journal. Volume 148, Issue 5, 1993, 1 Mar: pgs. $819-21$.

Peiffer, Jürgen. "Phases in the Postwar German Reception of the 'Euthanasia Program' (1939-1945) Involving the Killing of the Mentally disabled and ist Exploitation by Neuroscientists“. Journal of the History of the Neurosciences. Volume 15, 2006: pgs. 210-244.

Pelling, Margaret and Richard M. Smith, eds. Life, Death and the Elderly: Historical Perspectives. London: Routledge, 1991.

Peter, Jürgen. Der Nürnberger Ärzteprozess im Spiegel seiner Aufarbeitung anhand der $\underline{\text { drei Dokumentensammlungen von Alexander Mitscherlich und Fred Mielke. }}$ Münster and Hamburg: Sigmund-Freud-Institut LIT Verlag, 1994. 
Power, Samantha. "A Problem from Hell" America and the Age of Genocide. New York, New York: Basic Books, 2002.

Prainsack, Barbara. “'Negotiating Life': The Regulation of Human Cloning and Embryonic Stem Cell Research in Israel“. Social Studies of Science. Volume 36, Number 2, 2006 Apr: pgs. 173-205.

Pressel, David M. "Nuremberg and Tuskegee: Lessons for Contemporary American Medicine“. Journal of the National Medical Association. Volume 95, Number 12, 2003 Dec: pgs. 1216-25.

Proctor, Robert. Racial Hygiene: Medicine Under the Nazis. London: Harvard University Press, 1988.

Propping, Peter. "Abuse of Genetics in Nazi Germany“. Letter. American Journal of Human Genetics. Volume 51, 1992: pgs. 909-910.

Pross, Christian. "Breaking through the postwar cover-up of Nazi doctors in Germany". Journal of medical ethics. Volume 17, 1991: pgs. 13-16.

Rapp, Morton S. "Life devoid of value". Letter. Canadian Medical Association Journal. Volume 116, 197719 Mar: pg. 591. 
Rosen, George. "Medicine Under Hitler". The Bulletin. 1949 Feb: pgs. 125-129.

Sachse, Carola ed. Die Verbindung nach Auschwitz Biowissenschaften und Menschenversuche an Kaiser-Wilhelm-Instituten Dokumentation eines Symposiums. Göttingen: Reinhard Rürup und Wolfgang Schieder im Auftrag der Präsidentenkommission der Max-Planck-Gesellschaft, Wallstein Verlag, 2003.

Sanders, Joseph. "Euthanasia: None Dare Call It Murder". Journal of Criminal Law, Criminology, and Police Science. Volume 60, Number 3, 1969 Sep: pgs. 351359.

Schulze, Hagen. Kleine deutsche Geschichte. München: Deutscher Taschenbuch Verlag GmbH \& Co. KG, 1998.

Seidelmann, William E. "Medicine and Murder in the Third Reich". Dimensions: A Journal of Holocaust Studies. Volume 13, Number 1, 1999.

Seidelmann, William E. “Medicine's Worst Hour". Rev. of The Nazi Doctors. Medical Killing and the Psychology of Genocide by Robert Jay Lifton. Canadian Medical Association Journal. Volume 137, 198715 Nov: pgs. 917-918.

Shimkin, Michael B. "The Nazi Medical Crimes". The Scientific Monthly. Volume 69, Number 1, 1949 Jul: pg. 69. 
Shindell, Sidney. "Legal and Ethical Problems in the Provision of Medical Care". $\underline{\text { Yale }}$ Journal of Biology and Medicine. Volume 37, 1965: pgs. 394-401.

Shindell, Sidney. "The Care of the Terminally Ill". Yale Journal of Biology and Medicine. Volume 37, 1965: pgs. 401-408.

Slovenko, Ralph and William C. Super. "The Mentally Disabled, the Law and the Report of the American Bar Association“. The Virginia Law Review. Volume 47, Number 8, 1961 Dec: pgs. 1366-1387.

Smith, C.L. "The Experts at Hadamar". Biomolecular Engineering. Volume 17, Number 39, 2001.

Spring, Claudia Andrea. Zwischen Krieg und Euthanasie: Zwangssterlisationen in Wien 1940-1945. Wien, Köln and Weimar: Böhlau Verlag GmbH und Co., KG, 2009.

Stargardt, Nicholas. The Holocaust. New York, New York: Hodder Headline Group, 1997.

Strous, Rael D. "Images in Psychiatry: Nazi Euthanasia of the Mentally Ill at Hadamar". American Journal of Psychiatry. Volume 163, Number 1, 2006 Jan. 
Strous, Rael D. "Nazi Euthanasia of the Mentally Ill at Hadamar". American Journal of Psychiatry. Volume 163, Number 1, 2006 Jan: pg. 27.

Strous, Rael D. "Psychiatry during the Nazi era: ethical lessons for the modern professional““. Annals of General Psychiatry. Volume 8, Issue 8, 2007 Feb 27.

Strous, Rael D. "Psychiatric Genocide: Reflections and Responsibilities". The Author by Oxford University Press on behalf of the Maryland Psychiatric Research Center, 2010.

"The Nuremberg Code". Trials of War Criminals before the Nuremberg Military Tribunals under Control Council Law No. 10 by the United States Holocaust Memorial Museum. Nuremberg, October 1946-April 1949. Washington, D.C.: U.S. G.P.P, 1949-1953.

Thomson, Hugh J. "Abortion and euthanasia evoke thoughts of Nazi Germany“. Letter. British Medical Journal. Volume 314, 1997 Feb 8: pg. 439.

Thompson, Ian E. "Fundamental ethical principles in health care". British Medical Journal. Volume 295, 1987 Dec 5: pgs. 1461-1465. 
Torrey, E. Fuller and Robert H. Yolken. "Psychiatric Genocide: Nazi Attempts to Eradicate Schizophrenia“. The Author by Oxford University Press on behalf of the Maryland Psychiatric Research Center. Volume 36, Number 1, 2010: pgs. 2632.

Van Es, Adriaan. "Medicine and torture: A new BMA report makes clear doctors' responsibilities for human rights“. British Medical Journal. Volume 305, 1992 Aug 15: pg. 380.

Vesti, Peter and Niels Johan Lavik. "Torture and the medical profession: a review". Journal of medical ethics. Volume 17, 1991: Supplemental pgs. 4-8.

Vollman, Jochen and Rolf Winau. "Informed consent in human experimentation before the Nuremberg code“. British Medical Journal. Volume 313, 1996 Dec 7: pgs. 1445-1449.

Von Galen, Clemens August Graf. "Predigt von Galens zur Ermordung Behinderter". Informationene zur politischen Bildung. Volume 243, 2000: pg. 21.

Weindling, Paul. "Human guinea pigs and the ethics of experimentation: the BMJ's correspondent at the Nuremberg medical trial“". British Medical Journal. Volume 313, 1996 Dec 7: pgs. 1467-1470. 
Weindling, Paul. "The Survival of Eugenics in 20th-Century Germany". American Journal of Human Genetics. Volume 52, 1993: pgs. 643-649.

Woolhandler, Steffie and David U. Himmselstein. "The Silence of the Doctors: Fifty Years After Nuremberg“. Journail of General Internal Medicine. Volume 13, 1998 Jun: pgs. 422-423.

Wulf, Henrik and Stig Andur Pedersen and Raben Rosenberg. Euthanasie oder Über die Würde des Sterbens. Stuttgart: Ernst Klett Verlag, 1974.

Wulf, Henrik and Stig Andur Pedersen and Raben Rosenberg. "Philosophy of Medicine an Introduction“. Blackwell Scientific Publications: 1986, 1990.

Yeide Jr., Harry. Rev. of Death and Deliverance: Euthanasia in Germany 1900-1945. The New England Journal of Medicine. Volume 332/1772, Number 25, 1995 Jun 22.

Zielke, Roland. Sterilisation per Gesetz: Die Gesetzinitiativen zur Unfruchtbarmachung in den Akten der Bundesministerialverwaltung (1949-1976). Berlin: Die Buchmacherei, 2006. 


\section{APPENDIX A}

\section{CHRONOLOGY AND HISTORY OF OPERATION T-4}

\begin{tabular}{|c|c|c|}
\hline ca. 1938 & 1) & $\begin{array}{l}\text { Organized, but unordered euthanasia, "unnatural deaths in } \\
\text { German asylums“", begins. May have been a continuation of an } \\
\text { already existing practice (Aly, 35) }\end{array}$ \\
\hline 1 Sept. 1939 & 2) & $\begin{array}{l}\text { Adolf Hitler (hereafter AH) signs backdated authorization of } \\
\text { Operation T-4 (hereafter OT4) claiming that with it the Reich } \\
\text { provides merciful death for those asylum inmates selected by } \\
\text { psychiatric "experts" } \\
\text { Psychiatric "experts" paid 20RM (Reichsmarks) extra to visit } \\
\text { outlying asylums to determine those eligible for merciful death } \\
\text { The decree set into motion what would become Operation T-4 } \\
\text { "with few exceptions...[and] without its being recognized at all } \\
\text { (Bundesarchiv-Militärarchiv Freiburg, H 20, } 463 \text { (Bericht über } \\
\text { die Planung Schleswig vom 11-19.9.1941) } \\
\text { Outbreak of World War II, SD Killing Units shot asylums } \\
\text { inmates in occupied and annexed areas of Poland, Pomerania } \\
\text { and Prussia } \\
\text { OT4 lasted officially from } 1940 \text { to } 1945\end{array}$ \\
\hline Oct. 1939 & 1) & $\begin{array}{l}\text { Pomeranian patients deported to Danzig and shot (no EP) } \\
\text { Inmates in asylums began being registered on } 9 \text { October, } \\
\text { though most remained unregistered in } 1942 \\
\text { Several weeks later, questionnaires about asylum inmates were } \\
\text { sent by the Reichsinnenministerium to the directors of mental } \\
\text { institutions asking for a) types of illnesses, b) length of stay, c) } \\
\text { ability to work. At this time, the directors were unaware of the } \\
\text { reason for the questionnaires. After questionnaires were } \\
\text { returned, } 3 \text { of } 30 \text { advisors at OT4 decided who would live and } \\
\text { who would receive a merciful death. At the end of October, } \\
\text { transfer lists were sent from the Reichsverteidigungskommisar } \\
\text { for those to be sent to transition, i.e. death asylums } \\
\text { At the time processing began, a general number of mercy } \\
\text { deaths was determined, 65,000-70,000. The number was } \\
\text { exceeded by ca. } 275 \text { people when OT4 was suspended, or } \\
\text { "pause[d] for reorganization" (Aly, 23) }\end{array}$ \\
\hline 1940 & 1) & $\begin{array}{l}\text { OT4, though backdated, was not ordered as a result of any } \\
\text { existing Reich laws. AH wrote a secret letter authorizing OT4 } \\
\text { in 1939, but in order to prevent any post-war problems, the } \\
\text { Justizminister post-drafted the Gesetz über die Sterbehilfe für }\end{array}$ \\
\hline
\end{tabular}




\begin{tabular}{|c|c|c|}
\hline & 6) & $\begin{array}{l}\text { Lebensunfähige und Gemeinschaftsfremde } \\
\text { On April 3, based on notes taken at a meeting of the German } \\
\text { Gemeindetag, the attending mayors decided to send all OT4 } \\
\text { remains to relatives in urns as a body would provide evidence } \\
\text { of the "merciful death" } \\
\text { Also at this meeting, the Gemeindetag discussed the reasons } \\
\text { and justifications for OT4: a) they described the term } \\
\text { Lebensunwertesleben and why such people should be } \\
\text { euthanized, b) free space would make beds available for } \\
\text { military injuries and those who had worth to the Reich, c) OT4 } \\
\text { must be kept secret because outsiders would see it as illegal, } \\
\text { the Americans would see it as a reason to enter the war and the } \\
\text { church was opposed to cremation; and d) all remains were to be } \\
\text { sent to relatives in urns at no cost, with a death certificate } \\
\text { stating a general but believable cause of death (Aly, } 48-51 \text { ) } \\
\text { In April/May, the transports to holdover asylums began in } \\
\text { earnest. This trip camouflaged the real goal of sending inmates } \\
\text { to killing centers and prevented clerical errors } \\
\text { Beginning in the summer, all Jewish asylum inmates were } \\
\text { euthanized } \\
\text { On } 19 \text { November, a secret decree allowing abortions in cases } \\
\text { where an "undesirable" child was probable, came into } \\
\text { existence. This decree was in addition to the forced } \\
\text { sterilization that had been going on since the } 1920 \text { s }\end{array}$ \\
\hline 1941 & 1) & $\begin{array}{l}\text { The offices at Tiergartentrasse } 4 \text { (the headquarters of OT4 in } \\
\text { Berlin) committed } 100 \text { experts to help plan "the Final Solution } \\
\text { of the Jewish Question in the East" } \\
\text { In April of this year, a sister program to OT } 4 \text { was created, } \\
\text { Operation } 14 \mathrm{f} 13 \text {, to gas all prisoners unable to work by the } \\
\text { winter of } 1944 \text {. The program functioned under the auspices of } \\
\text { OT4 and made the eventual EP/OT4 (hereafter EP) possible } \\
\text { The EP, based on O } 14 \mathrm{f} 13 \text {, became the model for all Nazi } \\
\text { mass murders in World War II. Exceptions, at least on the } \\
\text { surface, were provided to inmates who were considered to be } \\
\text { Aryan, but were peremptorily examined by a physician and } \\
\text { often sent to death anyway } \\
\text { On } 23 \text { April a meeting took place to convince the German legal } \\
\text { system to participate in OT4 and O } 14 \text { f } 13 \text { and the ensuing } E P \text {. } \\
\text { AH's representative, Viktor Brack, made clear that the deaths } \\
\text { were justified, merciful and not destructive. "Neutral" terms } \\
\text { and "special mental hospitals specially equipped for humane } \\
\text { implementation" were going to be necessary in addition to a } \\
\text { determined list of illnesses that needed to be eliminated from } \\
\text { the Reich (Aly, } 45 \text { ) } \\
\text { On June 20, the Reichsministerium issued a new decree, }\end{array}$ \\
\hline
\end{tabular}




\begin{tabular}{|c|c|c|}
\hline & 8) & $\begin{array}{l}\text { Planwirtschaftliche Verwendung von Anstalten und Heimen zur } \\
\text { Unterbringung Minderjähriger, insbesondere für die Zweck der } \\
\text { erweiterten Kinderlandverschickung, that added minor aged } \\
14-17 \text { to the EP. At this time, mixed race children were } \\
\text { already being killed at Hadamar } \\
\text { On June 22, extermination begins in Russia and } \\
\text { simultaneously, the Final Solution. OT4 employees became } \\
\text { the directors of the Final Solution killing camps in the Third } \\
\text { Reich } \\
\text { On } 18 \text { July, Germans were divided into four categories, which } \\
\text { determined their fate in OT4: a) antisocial, b) acceptable, c) } \\
\text { average citizens and d) persons of particular genetic value (Aly, } \\
\text { 52) } \\
\text { In August, formal OT4 (with physician examinations, etc.) was } \\
\text { abandoned and exterminations of all "unusable“ inmates began } \\
\text { in earnest, the Final Solution, based on the 1940 Gesetz über } \\
\text { Sterbehilfre für Lebensunfähige und Gemeinschaftsfremde } \\
\text { On October 23, OT4 restarts with an expanded list of those to } \\
\text { be euthanized. This list now includes: a) public menace, b) } \\
\text { criminality requiring preventive detention, c) psychopathic } \\
\text { condition, d) ant sociality, e) racial/social inferiority. People } \\
\text { were killed for research purposes as well. }\end{array}$ \\
\hline 1942 & $\begin{array}{l}\text { 1) } \\
\text { 2) }\end{array}$ & $\begin{array}{l}\text { Patients in retirement homes, those with tuberculosis and } \\
\text { inmates in workhouses are added to the } E P \text { kill list } \\
\text { Due to extensive military defeats, the } E P \text { again expanded their } \\
\text { list of those deemed suitable for extermination to include } \\
\text { inmates in Soviet psych facilities. This expansion replaced the } \\
\text { research initiatives proposed by physicians who were perceived } \\
\text { to be new eugenicists. } \\
\text { Hans Heinze of OT4 clearly defines those considered to be } \\
\text { psychopaths or acts that are considered psychopathic: a) } \\
\text { prostitution, b) vagrancy, c) professional criminality, d) } \\
\text { pimping/pauperism for "endogenous" reasons and e) enemies } \\
\text { of society (swindlers, cheats, frauds, confidence tricksters, } \\
\text { hysterical scoundrels, provenly unstable, anti-social } \\
\text { psychopaths, common emotionally impoverished, prostitutes, } \\
\text { pimps, homosexuals, incorrigible shirkers) } \\
\text { Heinze publicly said "We hope that after the war, the fight } \\
\text { against or extermination of sub-humanity through purposeful } \\
\text { measure will take its honored place as a further great deed } \\
\text { beside those already accomplished" (ed. Gütt, vol. } 4 \text {, p. 286) } \\
\text { "How" of OT4 determined in October. Patients to be } \\
\text { suffocated "painlessly" by carbon monoxide gas (a.k.a. } \\
\text { disinfection) } \\
\text { By } 9 \text { October, most inmates were registered by Dept. IV, the }\end{array}$ \\
\hline
\end{tabular}




\begin{tabular}{|c|c|c|}
\hline & & $\begin{array}{l}\text { department at Tiergartenstrasse } 4 \text { that controlled OT4. } \\
\text { Euthanasia, was at this point, "integrated into daily asylum } \\
\text { routine" (Aly 35). }\end{array}$ \\
\hline 1943 & 4) & $\begin{array}{l}\text { Again, the parameters of those suitable for the } E P \text { to include: } \\
\text { slave labor no longer able to work, tuberculosis patients, } \\
\text { racially undesirable children of female slave laborers } \\
\text { In July, a group of } E P \text { professors suggested emptying all } \\
\text { psychiatric asylum beds to prepare for Nazi soldiers wounded } \\
\text { by Allied bombings } \\
E P / O T 4 \text { ends abruptly due to changes in the course of the war. } \\
\text { Indiscriminate killing takes over in order to provide hospital } \\
\text { beds for wounded Nazi soldiers } \\
\text { Specifically in Hadamar, relatives were offered a grace period } \\
\text { in which to apply for the release of their loved ones who were } \\
\text { not considered a danger to themselves or others or under police } \\
\text { detention. The relatives who allowed the grace period to expire } \\
\text { were considered complicit. This grace period was offered until } \\
1944 \text {. }\end{array}$ \\
\hline 1944 & 1) & $\begin{array}{l}\text { At the beginning of the year, the } E P \text { director, despite } \\
\text { Germany's power being on the decline, felt it important to } \\
\text { standardize mental health law in the Reich and to make OT4 } \\
\text { and } E P \text { an official, regulated and legal Reich office. The two } \\
\text { branches of the office would be practical work (finances) and } \\
\text { evaluation and execution of measure (i.e. euthanasia) }\end{array}$ \\
\hline 1945 & 1) & $\begin{array}{l}\text { As the war ends, EP/OT } 4 \text { has become the Final Solution and } \\
\text { was responsible for the murder of over } 6 \text { million Jews in } \\
\text { addition to innumerable other "undesirables" who polluted the } \\
\text { Reich. }\end{array}$ \\
\hline
\end{tabular}




\section{$\underline{\text { APPENDIX B }}$}

Predigt von Galens zur Ermordung Behinderter

Seit einigen Monaten hören wir Berichte, dass aus Heil- und Pflegeanstalten für Geisteskranke auf Anordnung von Berlin Pfleglinge, die schon länger krank sind und vielleicht unheilbar erscheinen, zwangsweise abgeführt werden. Regelmässig erhalten dann die Angehörigen nach kurzer Zeit die Mitteilung, die Leiche sei verbrannt, die Asche könne abgeliefert werden. Allgemein herrscht der an Sicherheit grenzende Verdacht, dass diese zahlreichen unerwarteten Todesfälle von Geisteskranken nicht von selbst eintreten, sondern absichtlich herbeigeführt werden, dass man dabei jener Lehre folgt, die behauptet, man dürfe sogenanntes „lebensunwertes Leben“ vernichten, also unschuldige Menschen töten, wenn man meint, ihr Leben sei für Volk und Staat nichts mehr wert. Eine furchtbare Lehre, die die Ermordung Unschuldiger rechtfertigen will, die gewaltsame Tötung der nicht mehr arbeitsfähigen Invaliden, Krüppel, unheilbar Kranken, Alersschwachen grundsätzlich freigibt.

[...] Noch hat Gesetzeskraft der $\S 211$ des Reichsstrafgesetzbuches, der bestimmt: „Wer vorsätzlich einen Menschen tötet, wird, wenn er die Tötung mit Überlegung ausgeführt hat, wegen Mordes mit dem Tode bestraft." Wohl um die-jenigen, die jene armen Menschen, Angehörige unserer Familien, vorsätzlich töten, vor dieser gesetzlichen Bestrafung zu bewahren, werden die zur Tötung bestimmten Kranken aus der Heimat abtransportiert in eine entfernte Anstalt. Als Todesursache wird dann irgendeine Krankheit angegeben. Da die Leiche sofort verbrannt wird, können die Angehörigen und auch die Kriminalpolizei es hinterher nicht mehr feststellen, ob die Krankheit wirklich vorgelegen hat und welche Todesursache vorliegt. Es ist mir aber versichert worden, dass man im Reichsministerium des Innern und auf der Dienststelle des Reichsärzteführers Dr. Conti gar kein Hehl daraus mache, dass tatsächlich schon eine grosse Zahl von Geisteskranken in Deutschland vorsätzlich getötet worden ist und in Zukunft getötet werden soll.

Das Strafgesetzbuch bestimmt in $§ 139$ : „Wer von dem Vorhaben [...] eines Verbrechens wider das Leben [...] glaubhaftte Kenntnis erhält und es unterlässt, der Behörde oder dem Bedrohten hiervon zur rechten Zeit Anzeige zu machen, wird [...] bestrafft." Als ich von dem Vorhaben erfuhr, Kranke aus Marienthal abzutransportieren, um sie zu töten, habe ich am 28. Juli bei der Staatsanwaltschaft beim Landgericht Münster und dem Herrn Polizeipräsidenten in Münster Anzeige erstattet durch eingeschriebenen Brief mit folgendem Wortlaut: „Nach mir zugegangenen Nachrichten soll im Laufe dieser Woche (man spricht vom 31. Juli) eine grosse Anzahl Pfleglinge der Provinzialheilanstalt Marienthal bei Münster als sogenannte, unproduktive Volksgenossen' mach der Heilanstalt Eichberg übergeführt werden, um dann alsbald, wie es nach solchen Transporten aus anderen Heilanstalten nach allgemeiner Überzeugung geschehen ist, vorsätzlich getötet zu werden. Da ein derartiges Vorgehen nicht nur dem göttlichen und natürlichen Sittengesetz widerstreitet, sondern auch als Mord nach § 211 des StGB mit dem Tode zu bestrafen ist, erstatte ich gemäss $\$ 139$ des StGB pflichtgemäss Anzeige und 
bitte, die bedrohten Volksgenossen unverzüglich durch Vorgehen gegen die den Transport und die Ermordung beabsichtigenden Stellen zu schützen und mir von dem Veranlassten Kenntnis zu geben."

Man urteilt: sie können nicht mehr Güter produzieren, sie sind wie eine alte Maschine, die nicht mehr läuft, sie sind wie ein altes Pferd, das unheilbar lahm geworden ist [...] Nein, hier handelt es sich um Menschen, unsere Mitmenschen, unsere Brüder und Schwestern. Arme Menschen, kranke Menschen, unproduktive Menschen meinetwegen. Aber haben sie damit das Recht auf das Leben verwirkt? Hast du, habe ich nur so lange das Recht zu leben, solange wir produktiv sind, solange wir von andern als "produktiv" anerkannt werden?

Wenn man den Grundsatz aufstellt und anwendet, dass man den „unproduktiven“ Mitmenschen töten darf, dann wehe uns allen, wenn wir alt und altersschwach werden! Wenn man die unproduktiven Menschen töten darf, denn wehe den Invaliden, die im Produktionsprozess ihre Kraft, ihre gesunden Knochen eingesetzt, geopfert und eingebüsst haben! Wenn man die unproduktiven Mitmenschen gewaltsam beseitigen darf, dann wehe unseren braven Soldaten, die als Schwerkriegsverletzte, als Krüppel, als Invaliden in die Heimat zurückkehren. Dann ist keiner von uns seines Lebens mehr sicher. Irgendeine Kommission kann ihn auf die Liste der „Unproduktiven“ setzen, die nach ihrem Urteil „lebensunwert" geworden sind. Und keine Polizei wird ihn schützen und kein Gericht seine Ermordung ahnden und den Mördern der verdienten Strafe übergeben. [...] (3. August 1941)

Quelle: Wolfgang Michalka (Hrsg.), Das Dritte Reich. Dokumente zur Innen-undAussenpolitik, band 2, Weltmachtanspruch und nationaler Zusammenbruch 1939-1945, dtv München 1985, S. 339 ff. 


\section{APPENDIX C From the United States Constitution}

Amendment 5 - Trial and Punishment, Compensation for Takings. Ratified 12/15/1791.

No person shall be held to answer for a capital, or otherwise infamous crime, unless on a presentment or indictment of a Grand Jury, except in cases arising in the land or naval forces, or in the Militia, when in actual service in time of War or public danger; nor shall any person be subject for the same offense to be twice put in jeopardy of life or limb; nor shall be compelled in any criminal case to be a witness against himself, nor be deprived of life, liberty, or property, without due process of law; nor shall private property be taken for public use, without just compensation.

\section{Amendment 14 - Citizenship Rights. Ratified 7/9/1868. Note History}

1. All persons born or naturalized in the United States, and subject to the jurisdiction thereof, are citizens of the United States and of the State wherein they reside. No State shall make or enforce any law which shall abridge the privileges or immunities of citizens of the United States; nor shall any State deprive any person of life, liberty, or property, without due process of law; nor deny to any person within its jurisdiction the equal protection of the laws.

2. Representatives shall be apportioned among the several States according to their respective numbers, counting the whole number of persons in each State, excluding Indians not taxed. But when the right to vote at any election for the choice of electors for President and Vice-President of the United States, Representatives in Congress, the Executive and Judicial officers of a State, or the members of the Legislature thereof, is denied to any of the male inhabitants of such State, being twenty-one years of age, and citizens of the United States, or in any way abridged, except for participation in rebellion, or other crime, the basis of representation therein shall be reduced in the proportion which the number of such male citizens shall bear to the whole number of male citizens twenty-one years of age in such State.

3. No person shall be a Senator or Representative in Congress, or elector of President and Vice-President, or hold any office, civil or military, under the United States, or under any State, who, having previously taken an oath, as a member of Congress, or as an officer of the United States, or as a member of any State legislature, or as an executive or judicial officer of any State, to support the Constitution of the United States, shall have engaged in insurrection or rebellion against the same, or given aid or comfort to the enemies thereof. But Congress may by a vote of two-thirds of each House, remove such disability.

4. The validity of the public debt of the United States, authorized by law, including debts incurred for payment of pensions and bounties for services in suppressing insurrection or rebellion, shall not be questioned. But neither the United States nor any State shall 
assume or pay any debt or obligation incurred in aid of insurrection or rebellion against the United States, or any claim for the loss or emancipation of any slave; but all such debts, obligations and claims shall be held illegal and void.

5. The Congress shall have power to enforce, by appropriate legislation, the provisions of this article. 


\begin{abstract}
APPENDIX D
Dritte Verordnung zur Ausführung des Gesetzes zur Verhütung erbkranken Nachwuchses.
\end{abstract}

Vom 25. Februar 1935.

Auf Grund des $\S 17$ des Gesetzes zur Verhütung erbkranken Nachwuchses vom 14. Juli 1933 (Reichsgesetzbl. I S. 529), des Artikels 5 des Gesetzes über den Neuaufbau des Reichs vom 30. Januar 1934 (Reichsgesetzbl. I S. 75) und des Artikels 5 des Ersten Gesetzes zur Überleitung der Rechtspflege auf das Reich vom 16. Februar 1934 (Reichsgesetzbl. I S. 91) wird verordnet:

\title{
Artikel 1
}

(1) Artikel 1 Abs. 2 Satz 3 der Verordnung zur Ausführung des Gesetzes zur Verhütung erbkranken Nachwuchses vom 5. Dezember 1933 (Reichsgesetzbl. I S. 1021) erhält folgende Fassung:

"Ein fortpflanzungsfähiger Erbkranken, der in einer geschlossenen Anstalt verwahrt wird, darf nicht entlassen oder beurlaubt werden, bevor die Unfruchtbarmachung durchgeführt oder der Antrag endgültig abgelehnt worden ist; dies gilt nicht, wenn der für die Anstalt zuständige Amtsarzt aus besonderen Gründen der Entlassung oder Beurlaubung ausnahmsweise zustimmt."

(2) Artikel 4 Abs. 2 der Zweiten Verordnung zur Ausführung des Gesetzes zur Verhütung erbkranken Nachwuchses vom 29. Mai 1934 (Reichsgesetzbl. I S. 475) fällt weg.

\section{Artikel 2}

(1) Einem Unfruchtbarzumachenden, der wegen krankhaften Geisteszustandes seine Belange nicht selbst wahrnehmen kann, ist von dem Erbgesundheitsgericht für dieses Verfahren ein Pfleger zu bestellen. Der Pfleger hat die Stellung eines gesetzlichen Vertreters. Der Unfruchtbarzumachende steht wegen Geistesschwäche entmündigten Personen gleich. Der Pfleger bedarf zur Stellung des Antrages auf Unfruchtbarmachung nicht der Genehmigung des Vormundschaftsgerichts.

(2) Ein Pfleger soll nicht bestellt werden, wenn der Unfruchtbarzumachende unter elterlicher Gewalt oder unter Vormundschaft steht, oder einen Pfleger für seine Person erhalten hat.

(3) In dem dem Antrag auf Unfruchtbarmachung beizufügenden ärztlichen Gutachten ist auch zu der Frage Stellung zu nehmen, ob die Bestellung eines Pflegers nach Abs. 1 erforderlich ist. 
(4) Die Pflegschaft endigt, falls das Gericht sie nicht früher aufhebt, mit der Durchführung der Unfruchtbarmachung oder der endgültigen Ablehnung des Antrags.

(5) Der Pfleger erhält Ersatz seiner notwendigen baren Auslagen aus der Staatskasse.

\section{A rtikel 3}

Artikel 2 Abs. 2 der Zweiten Verordnung zur Ausführung des Gesetzes zur Verhütung erbkranken Nachwuchses vom 29. Mai 1934 (Reichsgesetzbl. I S. 475) erhält folgende Fassung:

"Die Beisitzer der Erbgesundheitsgerichte und Erbgesundheitsobergerichte erhalten eine

Reisekostenvergütung nach den für die Reichsbeamten der Besoldungsgruppe A 2 geltenden Bestimmungen. Soweit die Beisitzer nicht dem Reich, bei den Ländern, Gemeinden (Gemeinde-Verbänden) oder Körperschaften des öffentlichen Rechts in einem festen Besoldungsverhältnis stehen, erhalten sie außerdem für den ihnen aus der Wahrnehmung des Beisitzeramtes erwachsenden Verdienstausfall eine Entschädigung in

Höhe von drei Reichsmark für jede angefangene Stunde der Sitzungsdauer und der Vorbereitung auf die Sitzung; die Vergütung für die Vorbereitung darf die für die Sitzung zu gewährende Vergütung nicht übersteigen."

\section{A rtikel 4}

Bevollmächtigten und Beiständen kann das Auftreten vor den Erbgesundheitsgerichten und Erbgesundheitsobergerichten aus wichtigen Gründen untersagt werden; der Beschluß ist unanfechtbar.

\section{Artike 15}

Falls der Beschluß des Erbgesundheitsgerichts oder Erbgesundheitsobergerichtes dem Unfruchtbarzumachenden persönlich zuzustellen ist, kann nach dem Ermessen des Gerichts von einer Mitteilung der Gründe abgesehen werden. Auf Verlangen ist dem Unfruchtbarzumachenden eine Ausfertigung des vollständigen Beschlusses kostenlos zu erteilen. Die Zustellung eines abgekürzten Beschlusses steht in den Wirkungen der Zustellung eines vollständigen Beschlusses gleich.

\section{A rtikel 6}

Die Beschwerde gegen den Beschluß des Erbgesundheitsgerichts kann auch bei dem Erbgesundheitsobergericht schriftlich oder zur Niederschrift der Geschäftsstelle dieses Gerichts eingelegt werden.

Artike 17 
Artikel 6 Abs. 3 der Verordnung zur Ausführung Gesetzes zur Verhütung erbkranken Nachwuchses vom 5. Dezember 1933 (Reichsgesetzbl. I S. 1021) erhält folgende

Fassung:

"Ist der Eingriff nach Urteil des ausführenden Arztes wegen besonderer Umstände mit Lebensgefahr für den Erbkranken verbunden oder aus einem anderen gesundheitlichen Grunde nicht alsbald durchführbar, so kann der zuständige Amtsarzt aus Antrag des Arztes, der den Eingriff ausführen soll, anordnen, daß die Vornahme des Eingriffs einstweilen unterbleibt. Die Aussetzung erfolgt auf bestimmt Zeit. Wiederholte Aussetzung ist zulässig. Die Aussetzung ist dem Erbgesundheitsgericht anzuzeigen."

\section{A rtikel 8}

(1) Der die Unfruchtbarmachung ausführende Arzt hat dem Erbgesundheitsgericht und dem beamteten Arzt einen schriftlichen Bericht über die Unfruchtbarmachung und das hierbei angewandte Verfahren spätestens zwei Wochen nach Vornahme des Eingriffs einzureichen.

(2) Ist die Heilung zur Zeit der Berichterstattung noch nicht abgeschlossen, so ist dies in dem Bericht zu vermerken und erneut zu berichten, sobald die Heilung erfolgt ist.

\section{Artike 19}

(1) Als Kosten des ärztlichen Eingriffs gelten:

die Kosten der Reise des Unfruchtbarzumachenden und seiner etwa notwendigen Begleitung in die Anstalt, in welcher der ärztliche Eingriff ausgeführt werden soll, die Kosten seines Aufenthalts in der Anstalt, solange dieser zur Ausführung des ärztlichen Eingriffs notwendig ist, die Kosten des ärztlichen Eingriffs selbst,

die Kosten einer während eines halben Jahres nach dem Eingriff etwa erforderlichen Nachbehandlung,

die Kosten, die aus einer Verwahrung des Erbkranken in einer geschlossenen Anstalt auf Grund des Artikels 1 Abs. 2 Satz 3 der Verordnung zur Ausführung Gesetzes zur Verhütung erbkranken Nachwuchses vom 5. Dezember 1933 (Reichsgesetzbl. I S. 1021) entstehen, solange der Erbkranke lediglich zur Verhütung der Fortpflanzung und nicht aus anderen Gründen in der Anstalt verwahrt worden ist.

(2) Die Kosten zu den Ziffern 1, 2 und 5 sind von den im $\S 13$ des Gesetzes bezeichneten Stellen auch dann zu übernehmen, wenn der Eingriff selbst nicht zur Ausführung kommt.

(3) Die Verpflichtung der Krankenkasse, die Kosten des ärztlichen Eingriffs zu tragen ( $\$ 13$ Abs. 2 Satz 1 des Gesetzes), umfaßt auch die im Abs. 1 Nrn. 1 bis 3 genannten Kosten des ärztlichen Eingriffs an einem nach § 205 der Reichsversicherungsordnung berechtigten Familienmitglied des Versicherten. Die im Abs. 1 Nrn. 4 und 5 genannten Kosten trägt die Krankenkasse nach den Vorschriften der Reichsversicherungsordnung 
über den Umfang der Leistungen, jedoch nur, wenn die Voraussetzungen für die Gewährung der Leistungen nach der Reichsversicherungsordnung erfüllt sind. (4) Soweit die Staatskasse die Kosten des ärztlichen Eingriffs trägt (§ 13 Abs. 2 Satz 2 des Gesetzes), sind die Kosten nicht erstattungsfähig, die nach dem Gutachten des Amtsarztes nicht zu den Kosten des ärztlichen Eingriffs im Sinne des Absatzes 1 gehören oder das Maß dessen übersteigen, was bei einem Hilfsbedürftigen von der öffentlichen Fürsorge zu übernehmen wäre. Die Vorschriften des § 13 Abs. 2 Satz 2 des Gesetzes und des Artikels 7 Abs. 2 der Verordnung zur Ausführung des Gesetzes zur Verhütung erbkranken Nachwuchses vom 5. Dezember 1933 (Reichsgesetzbl. I S. 1021) werden hierdurch nicht berührt. Die Feststellung der den Krankenkassen zur Last fallenden

Kosten erfolgt nach den Vorschriften der Reichsversicherungsordnung im Spruchverfahren.

Artike 110

(1) Solange die Unterbringung eines Minderjährigen zur Fürsorgeerziehung angeordnet ist, fallen die Kosten des ärztlichen Eingriffs an dem Minderjährigen dem Träger der Kosten der Fürsorgeerziehung nach den für diese geltenden Vorschriften zur Last; § 75 des Reichsgesetzes für Jugendwohlfahrt findet keine Anwendung.

(2) Die Verpflichtung der Staatskasse und der Krankenkasse nach $§ 13$ Abs. 2 des Gesetzes bleibt unberührt. Für die Verpflichtung der Krankenkassen ist im übrigen die Vorschrift des $§ 216$ Abs. 1 Nr. 1 der Reichsversicherungsordnung entsprechend anzuwenden.

\section{A rtikel 11}

(1) Soweit Krankenkasse, öffentliche Fürsorge, Träger der Kosten der Fürsorgeerziehung, Polizei oder Staatskasse bis zu dem auf die Verkündung dieser Verordnung folgenden Tage Kosten des ärztlichen Eingriffs getragen haben, können sie untereinander Rückersatz dieser Kosten auch dann nicht fordern, wenn sie nach dieser

Verordnung für die Übernahme der Kosten nicht zuständig waren.

(2) Fälle, die durch Festsetzung der Kosten bereits abgeschlossen sind, werden nur dann von dieser Verordnung berührt, wenn beim Inkrafttreten dieser Verordnung schriftliche Einwendungen gegen die Kostenfestsetzung vorliegen.

\section{Artike 112}

(1) Der Reichsminister der Justiz bestimmt Sitz und Bezirk der entscheidenden Gerichte und die Zahl der bei diesen einzurichtenden Kammern. Er kann die Ausübung dieser Befugnis den Oberlandesgerichtspräsidenten übertragen.

(2) Hinsichtlich der Verwaltung und Dienstaufsicht gelten die Erbgesundheitsgerichte als Teil des Amtsgerichts, die Erbgesundheitsobergerichte als Teil des Oberlandesgerichts.

(3) Die Zahl der ärztlichen Mitglieder und ihrer Vertreter bestimmt der Oberlandesgerichtspräsident nach dem Bedürfnis. 
Artike 113

(1) Die Mitglieder der entscheidenden Gerichte und ihre Stellvertreter werden bestellt:

für das Erbgesundheitsgericht im Bezirk des Landgerichts Berlin durch den

Präsidenten des Amtsgerichts Berlin;

für die übrigen Erbgesundheitsgerichte durch die Landesgerichtspräsidenten;

für die Erbgesundheitsobergerichte durch die Oberlandesgerichtspräsidenten.

(2) Die richterlichen Mitglieder werden für die Dauer des Geschäftsjahres, die ärztlichen Mitglieder für die Dauer von zwei Geschäftsjahren bestellt. Die ärztlichen Mitglieder sind auf Vorschlag der höheren Verwaltungsbehörde, in Berlin des Polizeipräsidenten, zu bestellen. Die Vorschläge der ärztlichen Mitglieder für die

Erbgesundheitsobergerichtebedürfen der Zustimmung des Reichsministers des Innern.

(3) Wird während der Amtszeit der Mitglieder die Bestellung neuer Mitglieder erforderlich, so werden diese für den Rest der Amtszeit bestellt.

(4) Die Reihenfolge für die Heranziehung der Beisitzer bestimmt der Vorsitzende vor Beginn des Geschäftsjahres für seine Dauer.

(5) Artikel 4 Abs. 1 der Verordnung zur Ausführung des Gesetzes zur Verhütung erbkranken Nachwuchses vom 5. Dezember 1933 (Reichsgesetzbl. I S. 1021) fällt weg.

Artikel 14

Die Amtszeit der beim Inkrafttreten dieser Verordnung im Amt befindlichen ärztlichen Mitglieder der Erbgesundheitsgerichte und der Erbgesundheitsobergerichte endet am 31.

Dezember 1935. Artikel 13 Abs. 3 gilt entsprechend.

Berlin, den 25. Februar 1935.

Der Reichsminister des Innern

Frick

Der Reichsminister der Justiz

Dr. Schlegelberger

Der Reichsarbeitsminister

Dr. Krohn 


\title{
APPENDIX E
}

\author{
Der Hippokratische Eid
}

Ich schwöre bei Apollon dem Arzt und bei Asklepios, Hygieia und Panakeia sowie unter Anrufung aller Götter und Göttinnen als Zeugen, daß ich nach Kräften und gemäß meinem Urteil diesen Eid und diesen Vertrag erfüllen werde:

Denjenigen, der mich diese Kunst gelehrt hat, werde ich meinen Eltern gleichstellen und das Leben mit ihm teilen; falls es nötig ist, werde ich ihn mitversorgen. Seine männlichen Nachkommen werde ich wie meine Brüder achten und sie ohne Honorar und ohne Vertrag diese Kunst lehren, wenn sie sie erlernen wollen. Mit Unterricht, Vorlesungen und allen übrigen Aspekten der Ausbildung werde ich meine eigenen Söhne, die Söhne meines Lehrers und diejenigen Schüler versorgen, die nach ärztlichem Brauch den Vertrag unterschrieben und den Eid abgelegt haben, aber sonst niemanden.

Die diätetischen Maßnahmen werde ich nach Kräften und gemäß meinem Urteil zum Nutzen der Kranken einsetzen, Schädigung und Unrecht aber ausschließen.

Ich werde niemandem, nicht einmal auf ausdrückliches Verlangen, ein tödliches Medikament geben, und ich werde auch keinen entsprechenden Rat erteilen; ebenso werde ich keiner Frau ein Abtreibungsmittel aushändigen.

Lauter und gewissenhaft werde ich mein Leben und meine Kunst bewahren.

Auf keinen Fall werde ich Blasensteinkranke operieren, sondern ich werde hier den Handwerkschirurgen Platz machen, die darin erfahren sind.

In wieviele Häuser ich auch kommen werde, zum Nutzen der Kranken will ich eintreten und mich von jedem vorsätzlichen Unrecht und jeder anderen Sittenlosigkeit fernhalten, auch von sexuellen Handlungen mit Frauen und Männern, sowohl Freien als auch Sklaven.

Über alles, was ich während oder außerhalb der Behandlung im Leben der Menschen sehe oder höre und das man nicht nach draußen tragen darf, werde ich schweigen und es geheimhalten.

Wenn ich diesen meinen Eid erfülle und ihn nicht antaste, so möge ich mein Leben und meine Kunst genießen, gerühmt bei allen Menschen für alle Zeiten; wenn ich ihn aber übertrete und meineidig werde, dann soll das Gegenteil davon geschehen. 